\title{
21. PETROLOGY, ISOTOPE GEOCHEMISTRY, AND ORIGIN OF DOLOMITE AND LIMESTONE ASSOCIATED WITH BASALTIC BRECCIA, HOLE 373A, TYRRHENIAN BASIN
}

\author{
Daniel Bernoulli, Geologisch-paläontologisches Institut der Universität Basel, Switzerland \\ Robert E. Garrison, Earth Sciences Board, University of California, Santa Cruz, California \\ and \\ Judith McKenzie, Geologisches Institut, Eidg. Tech. Hochschule, Zürich, Switzerland
}

\begin{abstract}
Basaltic breccias cored at Hole 373A contain four generations of internally resedimented interclast limestone and four generations of void-filling calcite cement. Two of the limestone generations are pelagic carbonate oozes that infiltrated from the sea floor into voids. The other two generations of limestone apparently originated as diagenetic sediment which was precipitated and deposited within breccia interstices. Superimposed upon this complex pattern of resedimentation and cementation were repeated episodes of brecciation and fracturing. Oxygen and carbon isotopic compositions indicate that cementation of the breccias and lithification of the carbonate sediments occurred at low temperatures characteristic of deep bottom waters. Much if not all of this sea-floor carbonate diagenesis may be related to low temperature, submarine alteration of basalt. Ferruginous dolomites which lie stratigraphically above the basalts likewise formed at low temperatures, probably also as a consequence of basaltic alteration in the submarine environment.
\end{abstract}

\section{INTRODUCTION}

In recent years, carbonate-cemented basaltic breccias frequently were recovered during coring and drilling on oceanic ridges and seamounts. Similar rocks occur also in many on-land eugeosynclinal terrains (cf. Garrison, 1974, and references therein). Coring at Hole $373 \mathrm{~A}$ in the central Tyrrhenian Basin (Figure 1) recovered breccias of this kind as well as ferruginous dolomite in the flank of a seamount. In the following paragraphs we analyze these rocks and reconstruct the events in their genesis, as deduced from petrology and from isotope geochemistry.

Water depth at Hole $373 \mathrm{~A}$ is 3507 meters, and coring first encountered basaltic rocks beneath 270 meters of Recent to Pliocene marl and thin volcanic ash layers. The drill penetrated about 187 meters of basaltic breccia and flow rock between subbottom depths of 270 and 457 meters; Cores 2 through 12 made sporadic recovery of these rocks. The site chapter gives further details of the coring and drilling operations.

Dietrich et al. (this volume) describe the petrology of the basalts, which have affinities to oceanic tholeiites as well as to high alumina basalts of the calcalkaline suite. Most of the basalt is porphyritic or amygdaloidal, and has phenocrysts of plagioclase in a groundmass of fine plagioclase, pyroxene, and glass or alteration products of glass. The matrix of some of the basalts shows extensive alteration to smectites, chorophaeite, or chlorite. Potassium-argon dating indicates their age is latest Miocene or earliest Pliocene (Barberi et al., this volume; Savelli and Lippanni, this volume).

The basal part of Core 2 contained a few pieces of ferruginous dolomite that apparently occurs immediately above the basaltic breccia. Cores 3 through 8 recovered basaltic breccias cemented in several kinds of carbonate sediments and cements. Our study of these sediments and cements reveals a complex sequence of sedimentological and diagenetic events that followed the main episode of breccia formation. In particular, employing the logic of carbonate petrology, we have identified several distinct generations of sediment infiltration into voids within the breccias, the process called internal resedimentation by carbonate petrologists (Sander, 1936: Bathurst, 1958). A series of low magnification photographs of thin sections illustrates the diagnostic textures through which we have unraveled this complicated history.

\section{FERRUGINOUS DOLOMITE}

The ferruginous dolomite at the bottom of Core 2 is a moderately well lithified but somewhat friable rock. It apparently lies beneath soft nannofossil marl and stratigraphically above basaltic breccia, but drilling has distorted the upper and lower contacts. Core 2 recovered about $30 \mathrm{~cm}$ of this dolomite in separate pieces interspersed with pieces of basalt and basaltic breccia. The dolomite is moderate brown (5YR 3/4) to light brown (5YR 6/4), with some mottling of these colors.

Texturally the dolomite is rather homogeneous and consists largely of euhedral to subhedral dolomite 


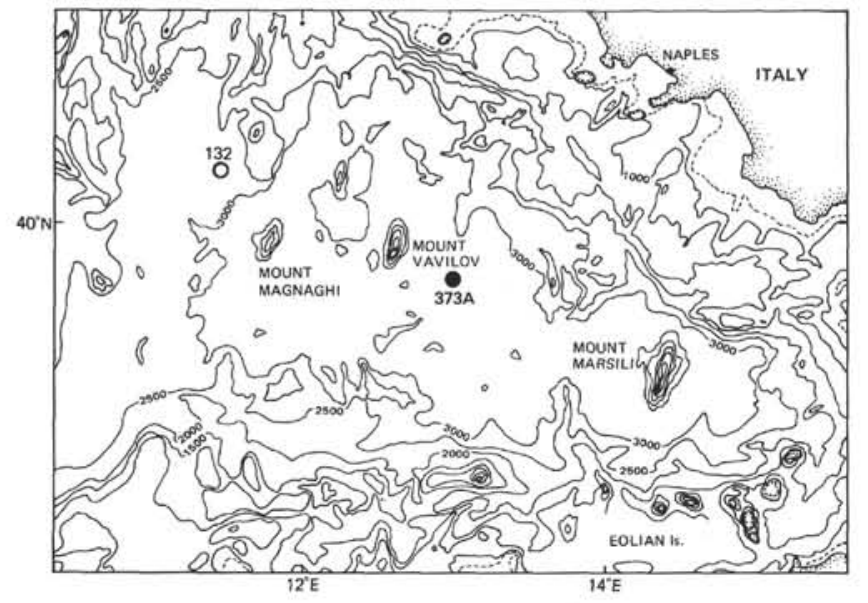

Figure 1. Map of location of Site $373 \mathrm{~A}$.

rhombs between 5 and $20 \mu \mathrm{m}$ across (Figure 2). Scattered through this dolomitic matrix are a few siltsize clasts of quartz, pyroxene, and feldspar, and irregularly shaped aggregations, 2 to $10 \mu \mathrm{m}$ across, of fine-grained reddish brown iron oxides. Also present are spherical vugs, a few hundred microns in diameter (Figures $2[\mathrm{~A}]$ and $2[\mathrm{~B}]$ ), filled partly or wholly by euhedral dolomite rhombs that are somewhat coarser and generally clearer than the dolomite in the surrounding matrix. They appear to be the molds of microfossils, probably foraminifers, into which voidfilling dolomite grew (Figure $2[\mathrm{C}]$ ).

$\mathrm{X}$-ray diffraction indicates the rock is about $79 \%$ dolomite, $6 \%$ quartz and feldspar, and $15 \%$ clay minerals. The dolomite is calcium rich, with about $5 \mathrm{~mol} \%$ excess $\mathrm{CaCO}_{3}$. Isotopic analysis (Table 1) sets some limits on the speculation about the origin of this dolomite. Its oxygen-18 content is too positive to have been precipitated from a hydrothermal solution. It is more consistent with formation at the ambient low temperature of normal deep marine water, although we initially considered the possibility that dolomitization was a consequence of contact metamorphism during basaltic intrusion.

Investigators associated with the experimental Mohole drilling initially made a somewhat similar interpretation of well indurated dolomite above basalt at the Guadalupe Site in the Pacific (Riedel et al., 1961;

TABLE 1

Isotopic Analysis of Carbonates Associated With Basaltic Breccias, Hole 373A

\begin{tabular}{|c|c|c|c|}
\hline Sample (Interval in cm) & $\begin{array}{c}\text { Carbonate } \\
\text { Mineral } \\
(100 \%)\end{array}$ & $\delta_{\mathrm{PDB}}^{18}$ & ${ }^{\delta} \stackrel{13}{\mathrm{PDB}}$ \\
\hline Dolomite, 2-2, 12-15 & Dolomite & $+5.37^{\mathrm{a}}$ & +3.28 \\
\hline P Limestone, 3-2, 48-52 & Calcite & +2.86 & +3.02 \\
\hline P Limestone, 3-2, 78-83 & Calcite & +2.97 & +3.00 \\
\hline P Limestone, 4-1, 74-75 & Calcite & +2.98 & +2.87 \\
\hline D Limestone, 4-1, 74-75 & Calcite & +2.98 & +2.87 \\
\hline C Cement, 7-1, 91-95 & Calcite & +3.02 & +2.92 \\
\hline
\end{tabular}

acorrected for Isotopic Fractionation according to Sharma and Clayton (1965).

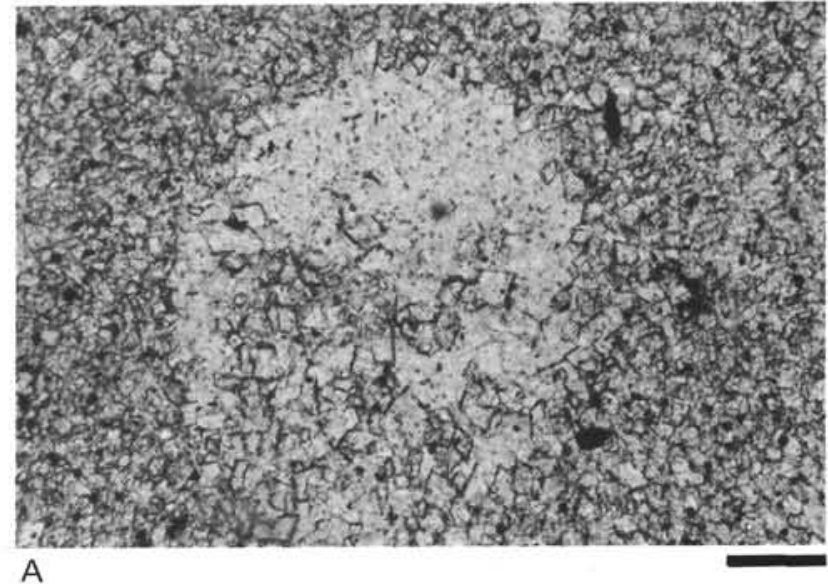

A

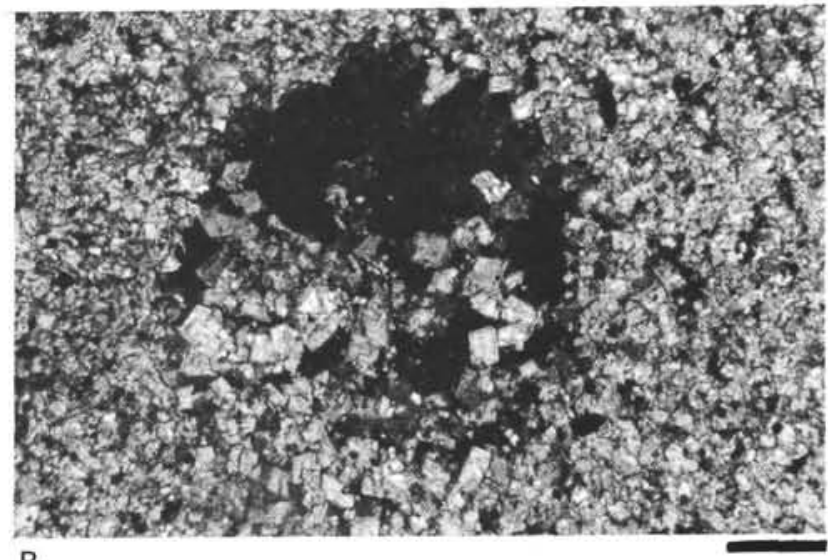

B

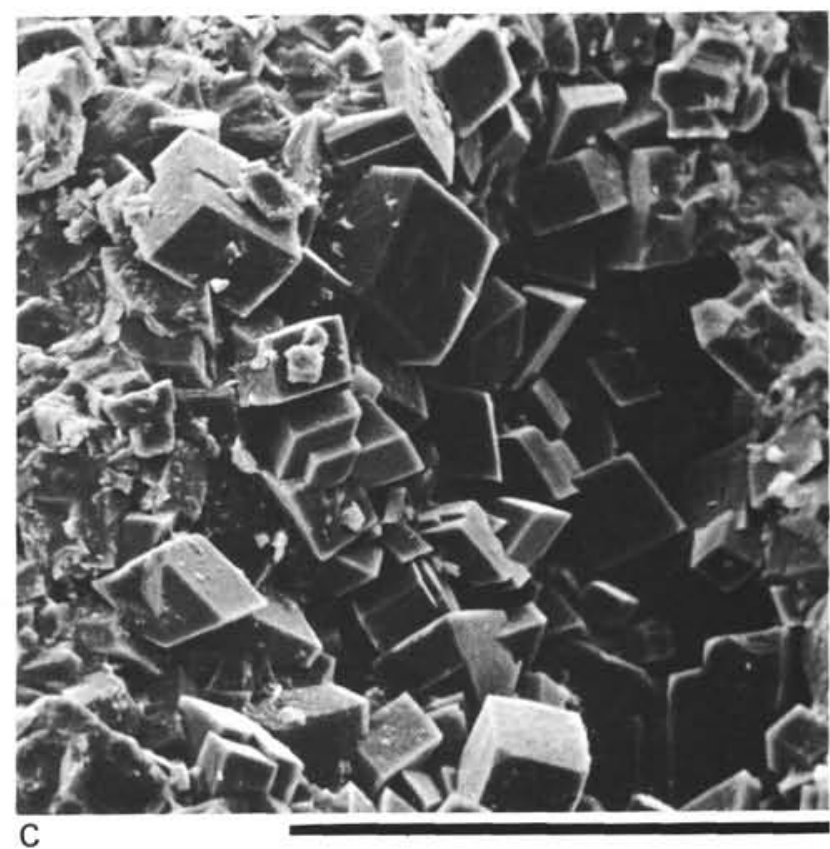

Figure 2. Dolomite lying above basalt at Hole 373A. (A) Photomicrograph showing foraminiferal mold (Orbuline?) in dolomitic matrix, with larger dolomite rhombs developing in the mold; plain light. (B) Same view, crossed nichols. (C) Scanning-electron micrograph of edge of foraminiferal mold with euhedral void-filling dolomite rhombs. All scale bars are $100 \mu \mathrm{m}$. Sample $373 A-2-1,141-144 \mathrm{~cm}$. 
Murata and Erd, 1964). Subsequent oxygen and carbon isotope analysis, however, yielded values similar to those at Hole 373A (although somewhat less positive) and suggested a crystallization temperature of about $5^{\circ} \mathrm{C}$ (Degens and Epstein, 1964).

Stable isotopic compositions nearly identical to the $\delta^{18}$ and $\delta^{13}$ values of the Hole $373 \mathrm{~A}$ dolomite were reported for calcium-rich dolomites found in the western Mediterranean (Fontes and Desforges, 1975). It was likewise concluded that this dolomite crystallization had occurred under cold marine conditions.

\section{CARBONATE-CEMENTED BASALTIC BRECCIA}

\section{General Petrology}

Basaltic breccia with interclast limestone matrix occurs in small amounts at the base of Core 2 and in Cores 3 and 4; such breccias form Unit IIIb in Hole 373A. Calcite-cemented breccias with smaller amounts of interclast limestone lie below these and are apparently interbedded with basaltic flow rocks; these latter breccias occur in Cores 5 through 8 and compose Unit IV. Below these are flow basalts, with no interlayered breccias, of Unit V (Cores 10-12).

As noted in the site description, the basalt clasts range from sand to boulder size and are very angular. One of the most notable characteristics of the clasts is that they comprise very different varieties of basalt. Among the more common kinds are unaltered glassy basalts with large plagioclase and/or pyroxene phenocrysts, palagonitized glassy basalts, and fine-grained holocrystalline basalts. Both vesicular and non-vesicular basalt is present, but the vesicular variety is the more common.

At the time of core recovery, we initially interpreted these rocks as pillow and broken pillow breccias of the kind described by Carlisle (1963) in western Canada. Further examination, however, has shown that the brecciation processes were more complicated and were of several different generations. Some of the breccias may have indeed formed initially by breakage of basalt pillows as they flowed on the sea floor (cf. Carlisle, 1963). Later stages of brecciation, however, were clearly epiclastic rather than magmatic. Very commonly the edges of clasts cut abruptly across the palagonitized rims of clasts and across phenocrysts (Figures 3 and 4 ), indicating that the brecciation of the basalt must be in part related to processes like slumping off steep slopes or tectonic fracturing. We call attention to the evidence in Figure 3 that substantial palagonitization preceded brecciation; this suggests that considerable time elapsed between eruption of the lava and filling of interbreccia voids with sediment. Still later stages of fracturing, probably of tectonic origin, affected the breccia following carbonate cementation, and produced fractures which cut across the diverse elements of the rocks (Figure 5).

\section{Interclast Sediments and Cements}

Several kinds of sediments and cements fill the space between basalt clasts and the vesicles and cracks within them. These are of four general varieties to which we give the following designations (Figures 3 and 5).

1) $T$ (for tuffaceous) sediment, composed mainly of altered basaltic fragments and only locally present.

2) $P$ (for pelagic) limestones are light reddish brown micritic limestones containing nannofossils and planktonic foraminiferal tests. At least two distinct generations $\left(\mathrm{P}_{1}\right.$ and $\left.\mathrm{P}_{2}\right)$ occur.

3) $C$ (for cement) calcites are clear sparry calcite cements that grew into void space and include four separate generations $\left(\mathrm{C}_{1}-\mathrm{C}_{4}\right)$.

4) $D$ (for diagenetic) limestones are light yellowish micritic limestones that are very homogeneous. We interpret them as products of redeposition of diagenetically formed calcite and recognize two generations $\left(D_{1}\right.$ and $\mathrm{D}_{2}$ ).

\section{Tuffaceous (T) Sediments}

These comprise very poorly sorted mixtures of angular basalt and palagonitized basalt grains and feldspar clasts in an ill-defined, fine-grained matrix of micrite, zeolites, and phyllosilicates (Figures 3 and 6). Locally, sparry calcite partly cements $\mathrm{T}$ sediments. These sediments are not everywhere present; they occur most commonly adjacent to basalt clasts whose palagonitic rims have been partly stripped, suggesting that $\mathrm{T}$ sediments may be very locally derived material (cf. Figure 3). Near the top of the sequence, formation of $\mathrm{T}$ sediments preceded deposition of $\mathrm{P}_{1}$ limestone, although it may have been in part contemporaneous with and gradational to $\mathrm{P}_{1}$. Lower in the sequence, where $\mathrm{P}$ limestones are absent, $\mathrm{T}$ sediments are succeeded by sparry calcite cements and diagenetic sediments (Figure 6). Still lower stratigraphically, they become the sole type of interclast sediment (Figure 7).

\section{Pelagic (P) Limestones}

These are lithified coccolith-foraminiferal oozes that filtered down from the sea floor into voids between and within basalt clasts. They have a number of textures (e.g., geopetal cavity fillings, sheltered cavities) that clearly indicate sediment infiltration, as opposed to intrusion of the breccias into a pre-existing ooze. Both $\mathrm{P}_{1}$ and $\mathrm{P}_{2}$ limestones contain admixtures of sand- to clay-size basaltic debris, but the amount of this decreases from the oldest $\left(\mathrm{P}_{1}\right)$ to the youngest $\left(\mathrm{P}_{2}\right)$ generation, as do also the numbers of foraminiferal tests. They lack any kind of lamination or other small sedimentary structures.

$P_{1}$ limestone is the oldest infiltrated sediment in these rocks. It precedes the precipitation of any sparry calcite cement and occurs either cemented directly to basalt clasts (without any intervening sparite; Figure 5) or as angular to subrounded clasts (Figure 8). It commonly also forms geopetal floors overlain by sparite roofs in vesicles (Figure 9). Compositionally, $\mathrm{P}_{1}$ limestone is somewhat impure and consists mainly of foraminiferal shells and sand-size basaltic fragments in a matrix of micrite, fine-grained ferric oxides, clay minerals, and fine-grained volcanic debris. $\mathrm{P}_{1}$ sediment infiltrated between basalt clasts and became lithified, 


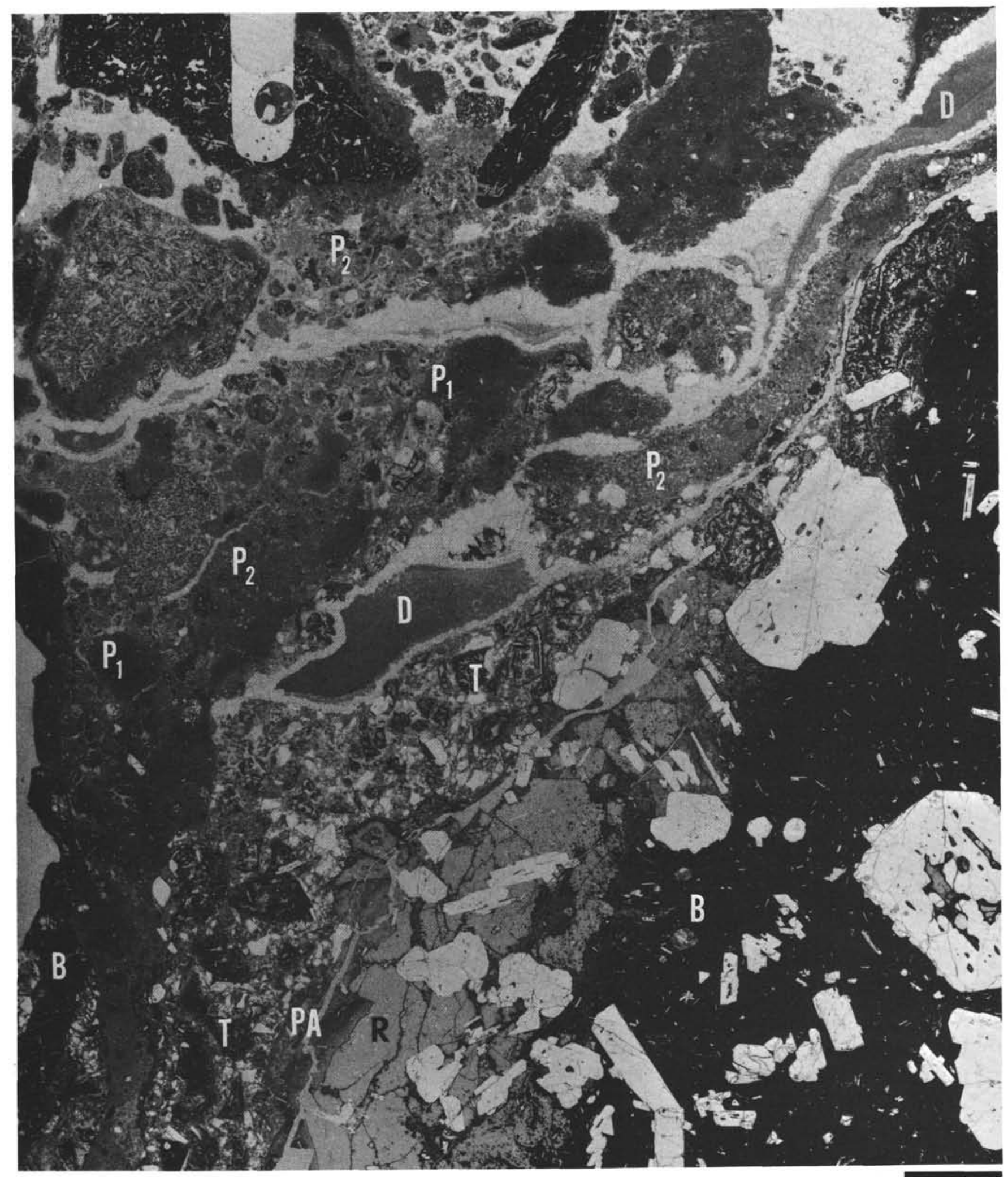

$2 \mathrm{~mm}$

Figure 3. Thin-section photograph of breccia with complex sequence of interclast filling. The edges of large porphyritic basalt clasts, labeled $B$, are at lower left and right. The clast at right has a palagonitized rim (PA) lying outside a rim of light brown sideromelane $(R)$, which in turn coats dark tachylytic basalt. Note how brecciation progressively cuts across the palagonite and sideromelane rims toward the upper right; note also that the brecciation has cut across plagioclase phenocrysts. The sediment labeled $T$ is a poorly sorted mass of angular palagonite and feldspar grains which are 
cemented in sparry calcite, sparse micrite, and fine-grained zeolites and phyllosilicates; this material may have been derived from the brecciated clast edge at upper right. Poorly defined clasts of partly zeolitized $P_{1}$ limestone (a few are labelled) reside in $P_{2}$ limestone, which itself has been brecciated. Cutting across all these elements toward the top are a number of fractures that became filled with several generations of sparry calcite cement (white) and diagenetic sediment (D). Notch in the thin section at upper left indicates stratigraphic top. Scale bar is $2 \mathrm{~mm}$. Sample 373A-3-3, 129-132 $\mathrm{cm}$.

then itself became brecciated so that it now occurs as clasts and also adhered to the sides and undersides of basaltic clasts (i.e., not perched on top of them; cf. Figure 8). As described later, zeolites and other secondary minerals replace $P_{I}$ limestone in places.

$P_{2}$ limestone is a biomicrite similar to $\mathrm{P}_{1}$, but has fewer foraminiferal shells and fine basalt clasts and has a somewhat lighter color. In some places it forms the matrix surrounding $\mathrm{P}_{1}$ clasts, in other places it occurs itself as clasts cemented in $C_{1}$ sparry calcite. Many clasts of $\mathbf{P}_{2}$ limestone have very irregular or indistinct edges; these clasts appear to have been broken fragments of a weakly lithified, crumbly limestone. In places the $\mathrm{P}_{2}$ clasts are rather small and enclosed in abundant $\mathrm{C}_{1}$ cement giving the rock a texture resembling structure grumeleuse (Cayeux, 1935) (see later discussion of this texture). Locally, such $\mathrm{P}_{2}$ limestones also resemble the internally resedimented pellet silts described by Dunham (1969; see his fig. 13) in Permian limestones of New Mexico. It becomes difficult in places to distinguish between $\mathrm{P}_{1}$ and $\mathrm{P}_{2}$ limestones. In addition, some $\mathrm{P}_{2}$ limestone actually may be reworked $\mathrm{P}_{1}$ sediment.

The micritic fraction of $\mathrm{P}_{1}$ and $\mathrm{P}_{2}$ limestones contains coccoliths that show rather extensive secondary overgrowths and replacement textures (Figure 10). Planktonic foraminifers present in these limestones indicate a Pliocene age (G. Bizon, personal communication, 1975). Among the common genera are Orbulina, Globigerinoides, Globorotalia, and Globigerina.

In addition to $\mathrm{P}_{1}$ and $\mathrm{P}_{2}$, some specimens contain suggestions of a third generation of pelagic sediment infiltration. This is foraminifer-poor micrite with structure grumeleuse, and locally it appears to enclose pieces of $\mathrm{P}_{1}$ and $\mathrm{P}_{2}$ limestones. It is, however, so sparse and poorly developed that we have been unable to document it adequately.

\section{Calcitic (C) Cements}

Clear, void-filling sparry calcite cement occurs in four generations, all of which are younger than the $P$ limestones. $C_{1}$ spar forms the cement which encloses clasts of $\mathrm{P}$ limestones (Figure 11). $\mathrm{C}_{2}$ spar rims fractures (Figure 5) and interclast voids which $\mathrm{P}$ sediment did not completely fill (Figures 6, 8, and 12). In some instances it is not possible to separate $C_{1}$ from $C_{2} \cdot C_{3}$ spar is sparse; generally, it can only be recognized as a thin crust, a few tens of microns or less thick, that lies on top of $\mathrm{D}_{1}$ sediment (Figures 8, 12, and 13). Most likely it represents only a very brief period of cement precipitation during a short pause in internal resedimentation. In many places $C_{3}$ is missing, either because it did not form or because internal erosion removed it. $\mathrm{C}_{4}$ calcite formed a rim cement that lies above $\mathrm{D}_{2}$ sediment or commonly lines unfilled voids (Figures 13, 14 , and 15 ).

These cements are magnesium calcite with 4 to 7 mol \% $\mathrm{MgCO}_{3}$, as determined by electron microprobe analysis and by Debye-Scherrer X-radiography using the calibration of Goldsmith and Graf (1958). Many of the cements show fabrics indicative of crystal growth into void space (cf. Bathurst, 1975, chapter 10), such as increase in crystal size away from the substrate, crystal elongation perpendicular to this surface, geopetal textures, etc. (see Figures 12, 14, and 15). In some, however, the spar has a blocky, somewhat recrystallized appearance (Figure 9).

These calcite cements have a number of other distinctive textural relationships. One is the tendency of the calcitic rim cements on the tops of former voids (interparticle voids or open fractures) to be much thicker than those on the bottoms (cf. Figures 4, 5, 8, $13,14[\mathrm{C}], 14[\mathrm{D}]$, and 14). This results from the growth of several generations (in some cases $C_{1}$ through $\mathrm{C}_{4}$ ) from the ceilings of voids, whereas deposition of D sediment on void floors prevented or masked continuous spar growth there. Figure 13 shows how competition for space between diagenetic sediment and void-filling calcite can affect the thickness of the rim cement. Rim cements also tend to be thicker on the steep sides of former voids (Figure 12), these sides being, like the ceilings, surfaces of non-deposition.

Whereas diagenetic sediment tended to become perched on top of large clasts (Figures 8 and 12), very thick calcitic rim cements formed in sheltered cavities below large clasts that inhibited infiltration on pelagic and diagenetic sediment (Figures 5, 8 and 15). This is analogous to the "umbrella effect" of bivalve and other large shells in carbonate rocks (e.g., Dunham, 1969).

\section{Diagenetic (D) Limestones}

Following precipitation of $\mathrm{C}_{2}$ cement, a new kind of sediment began to infiltrate unfilled voids. This sediment differs markedly from the P limestones. It now forms pale yellow $(2.5 \mathrm{Y} 8 / 4)$ to light yellowish brown $(2.5 \mathrm{Y} 6 / 4)$, fine-grained, rather homogeneous limestone that has pronounced layering. It contains no planktonic foraminifers or other skeletal debris, nor does it have volcanic clasts. Most of it is even grained micritic limestone. In contrast to the $\mathrm{P}$ limestones, electron microscopy indicates the micrite consists only of a blocky neomorphic mosaic with extremely rare nannofossils (Figure 16). These D limestones fill both interclast space which was unfilled by $P$ sediments (Figures 4, 8 and 15) and open fractures, generally horizontal or subhorizontal, that formed following 


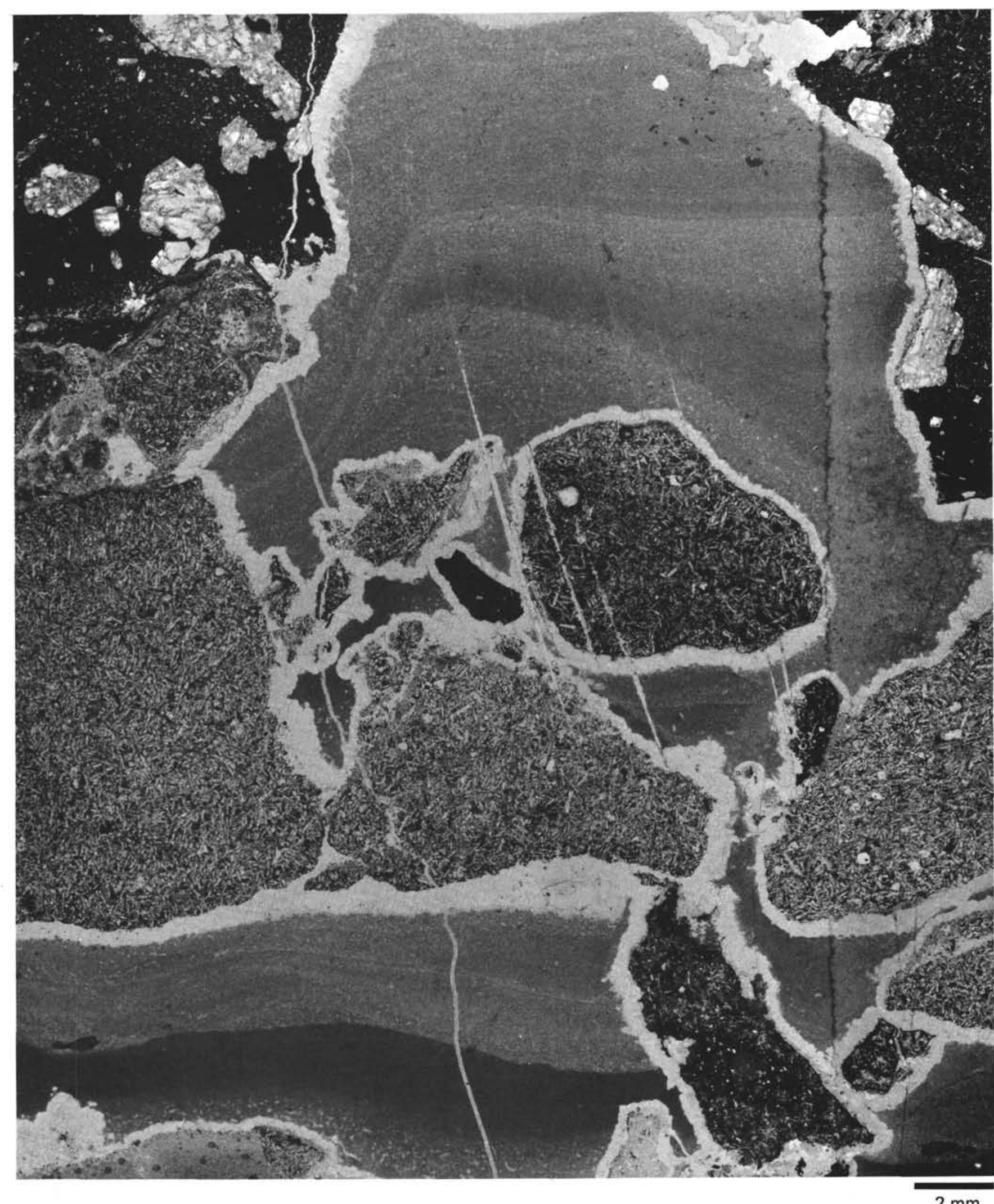

$2 \mathrm{~mm}$

Figure 4. Thin-section photograph of breccia; interclast spaces filled mainly with laminated, inversely graded diagenetic limestone. Note variety of basalt clasts, truncated plagioclase phenocrysts at upper right, contrast in thickness of floor and ceiling sparite, and steeply inclined laminae at upper left center. We believe the latter are primary features caused by constriction of currents at the edge of a void. Also present are steeply inclined thin calcite veins at the center. Vertical dark line toward right is an artifact of thin section preparation. Scale bar is $2 \mathrm{~mm}$. Sample 373A-4-3, 72-75 cm. 


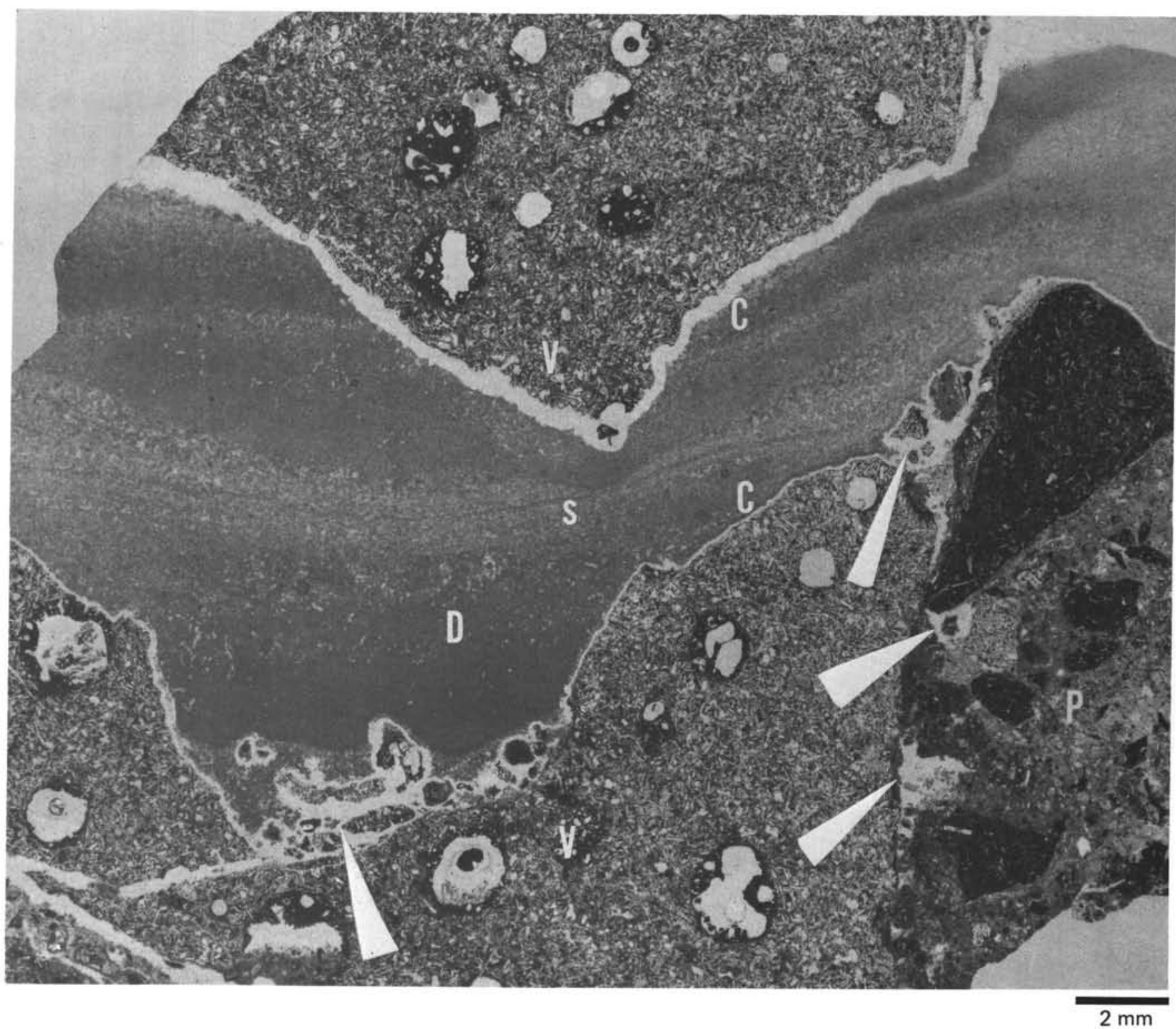

Figure 5. Thin-section photograph of breccia showing various components. $V$ is a large clast of amygdular basalt that was fractured across the middle; note how the edges fit, and note that the fracture also cuts across limestone breccia (P) at right. $P$ is pelagic limestone containing clasts of older pelagic limestone and dark, angular clasts of basalt. $C$ is calcite rim cement, that grew along both edges of the open fracture; note that the cement rim at the top of the fracture is much thicker than that at the bottom. D is diagenetic limestone that filled the open fracture. It contains reversely graded laminae of micritic to pelleted layers; note evidence of erosional scour just above the letter " $S$." Note also the small pieces of spar-rimmed basalt that accumulated in the bottom of the fracture at lower left (see also Figure 17). Arrows indicate sheltered cavities below basalt clasts, later filled by sparry calcite cement. Note also that many vesicles in the large basalt clast are filled by sparite or sparite and pelagic limestone (cf. Figure 9). Scale bar is $2 \mathrm{~mm}$. Sample 373A-3-3, 32-40 cm.

lithification of P limestones (Figures 3, 5, 6, 13, and 14).

This sediment thus seems to be not mainly of biogenic origin like the pelagic oozes that filtered down from the sea floor to form the P limestones. We are not completely certain of its origin. We believe, however, that it formed as a diagenetic precipitate of calcium carbonate which became internally resedimented by water currents moving through the breccia interstices. We have thus designated these as D limestones, and we believe they are broadly comparable to the diage- netic carbonate silts described by Dunham (1969), although at Hole 373A these sediments were mainly of clay size. Possibly the small carbonate grains which constituted the bulk of the original diagenetic sediment at Site 373A were crystallites that nucleated on void walls, but were subsequently eroded and redeposited by currents. Later they were overgrown and lithified by calcite cement to form blocky mosaics of the kinds shown in Figure 16.

Our evidence for the diagenetic origin is mostly circumstantial. As noted, the D limestones lack fossils 

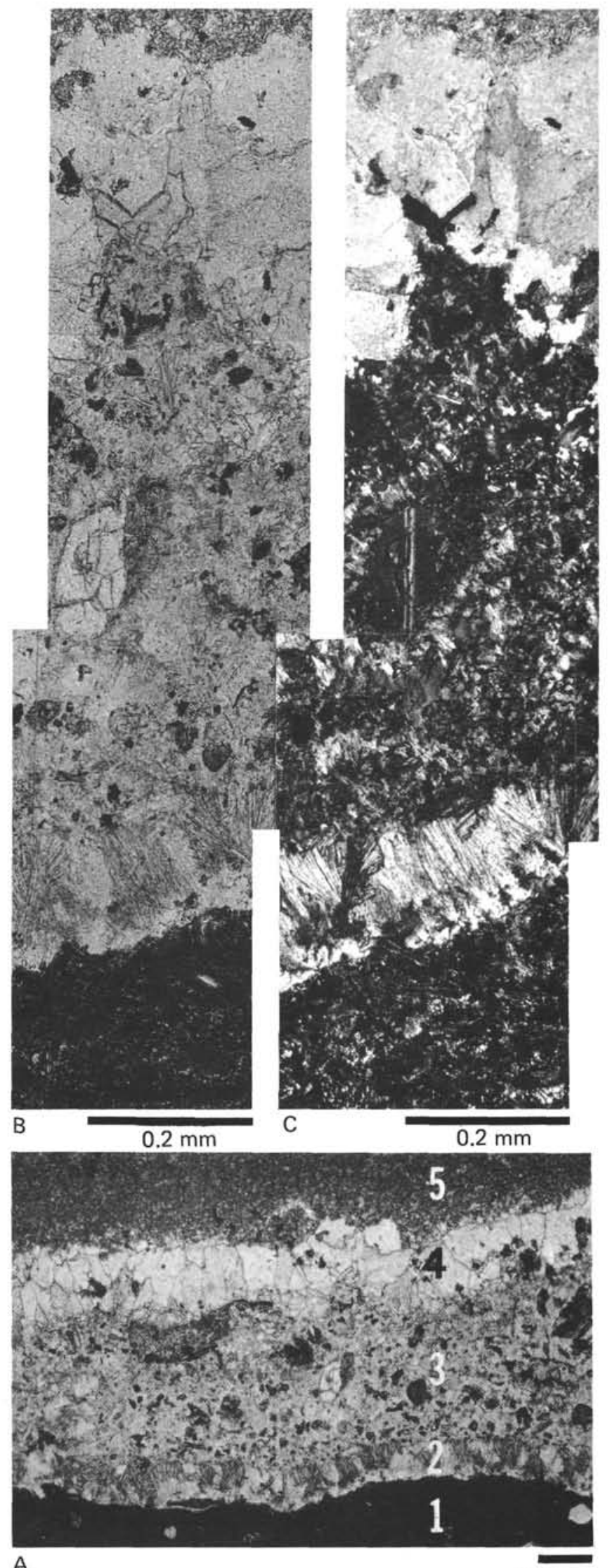

$0.2 \mathrm{~mm}$

Figure 6. Photomicrographs of interclast sediments and cements in breccia of Core 4. (A) General view with, from bottom to top: 1, edge of large basalt clast. 2, rim of unidentified platy or fibrous mineral. 3, poorly sorted volcanic sediment ( $T$ sediment), highly altered. $4, C_{2}$ calcitic rim cement. $5, P_{1}$ diagenetic limestone. $(B, C)$ enlargements of the center part of $(A) ;(B)$ plain light, (C) crossed nichols. Calcitic rim cement contains elongated phillipsite crystals (the dark crystals in the top part of (C). Scale bars are $200 \mu \mathrm{m}$. Sample 373A-4-2, $98.102 \mathrm{~cm}$.

except for very rare nannofossils. In addition, their genesis always followed the onset of calcite cementation (all $\mathrm{D}$ limestones are of post- $\mathrm{C}_{2}$ age), thus they formed only after inorganic precipitation had become an important process. Finally, their isotopic geochemistry, discussed later, is compatible with inorganic precipitation at low temperatures.

Not all of the diagenetic limestones are perfectly homogeneous micrites. Some layers consist of irregularly shaped, poorly defined, clots of micrite that are 50 to $100 \mu \mathrm{m}$ in dimension and resemble pellets (Figures 5, 12, 13, and 17). Like similar bodies in some $\mathrm{P}_{2}$ limestones, these have some affinities to the "crumblike pellet silt" of Dunham (1969), and finegrained sparry calcite also cements them, producing a texture akin to the structure grumeleuse of carbonate petrologists (Cayeux, 1935). Bathurst (1975, p. 511513 ) summarized uncertainties about the origin of this structure and listed two opinions: either the texture results from patchy neomorphic recrystallization of a micrite or from cementation of a pelletal sediment. Our observations suggest the latter origin in the diagenetic sediment at Hole 373A, where structure grumeleuse shows pronounced stratigraphic control (Figures 4, 5, 12,13 and 17), and where some interpellet space remains as spar-lined, unfilled pores. However, we do not know the origin of the irregular pellets.

Alternation of homogeneous micritic and pelletal laminae gives the diagenetic sediments a pronounced layering and indicate particle size sorting during transportation and deposition by water currents. The two lithologies noted above commonly form reversely graded laminae, with homogeneous micrite at the base, clotted pellets at the top (top part of Figure 4, Figure $5)$. Laminae tend to fill in depressions and level irregularities on the floors of the cavities they fill, suggesting cavity filling was a gradual, current-induced process. Small-scale scour features within the diagenetic sediment (Figure 5) also indicate current activity. Already noted is the perching of diagenetic sediment on the tops of steep-sided prominences (Figures 8 and 12 ). Where the floors had less relief, layers of diagenetic sediment initially draped over protuberances (Figures 5, 15, and 17). In such places, particularly in areas where large voids were filled with diagenetic sediment, the laminae are steeply inclined toward the edges of the adjoining basalt clasts (Figure 4). We believe these inclined laminae were sedimentary surfaces formed where water currents became constricted at void margins.

Most of the sparry calcite in the diagenetic sediment appears to be void-filling cement. Because they were encased in the rigid framework of a cemented breccia, 

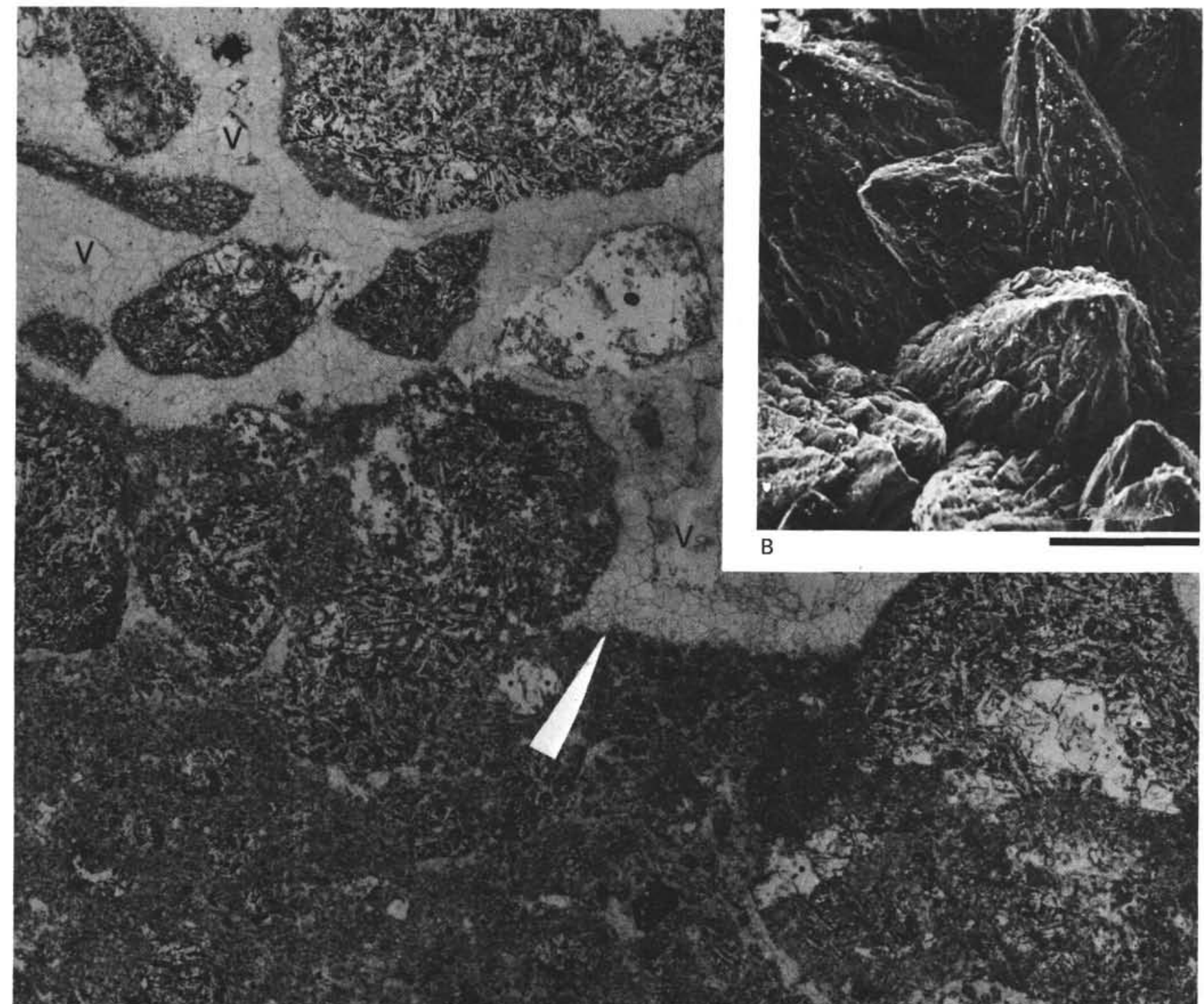

B

A

Figure 7. (A) Thin-section photograph of breccia in Core 7. At this level the only interclast sediment is volcanic debris cemented in sparry calcite. The arrow indicates a flat geopetal floor of this sediment between two larger basalt clasts. Sparry calcite (white) fills the remainder of interclast space, except for a few voids $(V)$. Note presence of spar-filled sheltered areas on left. Scale bar is $2 \mathrm{~mm}$. (B) Scanning electron micrograph showing scalenohedral form of void-filling calcite cement in this specimen. Scale bar is $200 \mu \mathrm{m}$. Sample 373A-7-1, 91-95 cm.

these diagenetic sediments probably experienced relatively little compaction, thus preventing flattening and merging of the pellets (cf. Beales, 1965), and leaving considerable interpellet pore space to be filled with spar cement.

If this fine-grained limestone is mainly diagenetic sediment, as we have tentatively concluded, its grain size and relative homogeneity suggests that the currents which eroded, transported and deposited it were relatively weak. Usually, for example, they were not capable of eroding and transporting coarser silt and sand size particles, such as sparite crystals or volcanic fragments. Dunham (1969) concluded that the lack of clay-size carbonate particles in the vadose diagenetic silts he studied was due to their destruction by abrasion and by dissolution during transport in undersaturated fresh water. In constrast, their abundance in Hole 373A might be viewed as a consequence of less vigorous currents and of pore waters saturated with respect to calcium carbonate.

We have recognized two generations of diagenetic limestone. $\mathrm{D}_{1}$ limestone formed after $\mathrm{C}_{2}$ cement, but before $C_{3} . D_{2}$ limestone formed between precipitation of $\mathrm{C}_{3}$ and $\mathrm{C}_{4}$ cements (Figures 12 and 13 ). When $\mathrm{C}_{3}$ is not present, however, it is not possible to separate $D_{1}$ and $\mathrm{D}_{2}$ limestones (Figures 14 and 15).

\section{Zeolitization and Other Alteration}

Zeolites, identified by X-ray diffraction as phillipsite, occur in small amounts throughout the breccias in two 


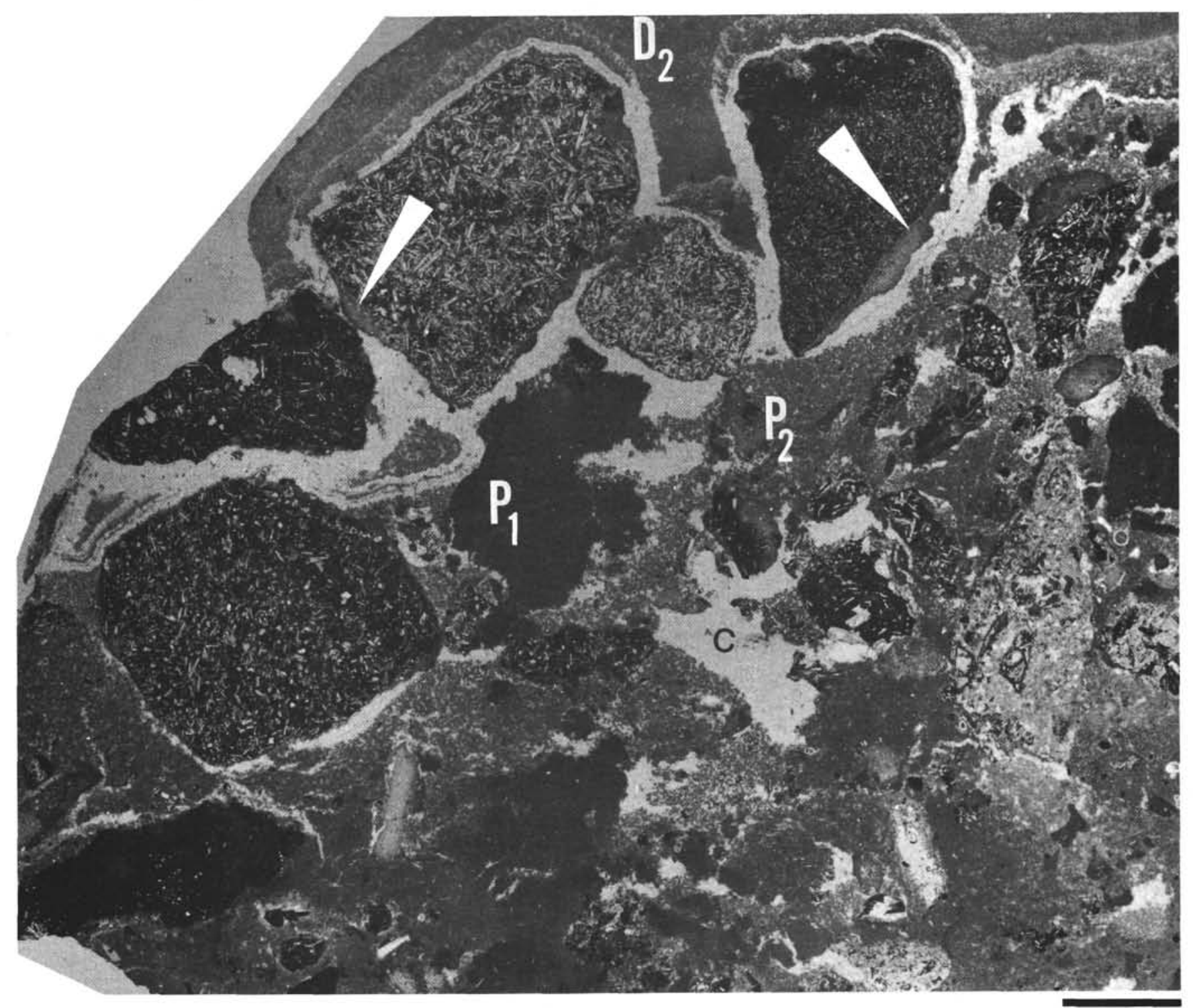

$2 \mathrm{~mm}$

Figure 8. Thin-section photograph of breccia. The main breccia components are angular pieces of porphyritic basalt and very irregular clasts of $P_{1}$ limestone (one of which is labelled). Some of the basalt fragments have partial rims of $P_{1}$ limestone cemented to their edges; $t$ wo such occurrences are indicated by arrows. The clasts of basalt and $P_{1}$ limestone are cemented in $P_{2}$ limestone and sparry calcite $\left(C_{1}\right.$, not labeled). Later generations of sparry calcite cement are most visible as rims around the darker clasts. Note the larger areas of spar beneath large clasts or groups of clasts that form shelters or "umbrellas" during sediment infiltration; the letter " $c$ " indicates the largest of the sheltered areas. Diagenetic limestone, including $\mathrm{D}_{2}$, is most prominent at the top of the thin section (see Figure 12). Scale bar is $2 \mathrm{~mm}$. Sample 373A-3-3, 76$78 \mathrm{~cm}$.

major forms: (1) as replacements of micrite and finegrained volcanic debris, and (2) as void-filling, elongate, euhedral crystals. Zeolitic replacement of carbonates preferentially affected the micritic matrix of $P_{1}$ limestone (Figure 11); $\mathrm{P}_{2}, \mathrm{D}_{1}$, and $\mathrm{D}_{2}$ limestones appear unaffected by zeolitization. In places, elongate phillipsite crystals fill small interparticle voids, vesicles, and fractures. Some of the latter have mixed fillings of phillipsite intergrown with $\mathrm{C}_{2}$ sparry calcite (Figures 6 , 18 , and 19). We may thus identify at least two periods of zeolite growth. The first followed deposition of $\mathrm{P}_{1}$ limestone, the second was contemporaneous with precipitation of $\mathrm{C}_{2}$ calcite.

A second, unidentified silicate material occurs as rosettes of platy or fibrous, birefringent minerals that form rim cements around basaltic clasts, particularly palagonitized ones (Figures 11 and 20). This same material also replaces fine-grained volcanic debris in $\mathrm{P}_{1}$ sediment and completely fills some fractures and small pores. We were unable to separate any of this material for x-ray diffraction, but electron microprobe analysis suggests that more than one mineral phase is present. 


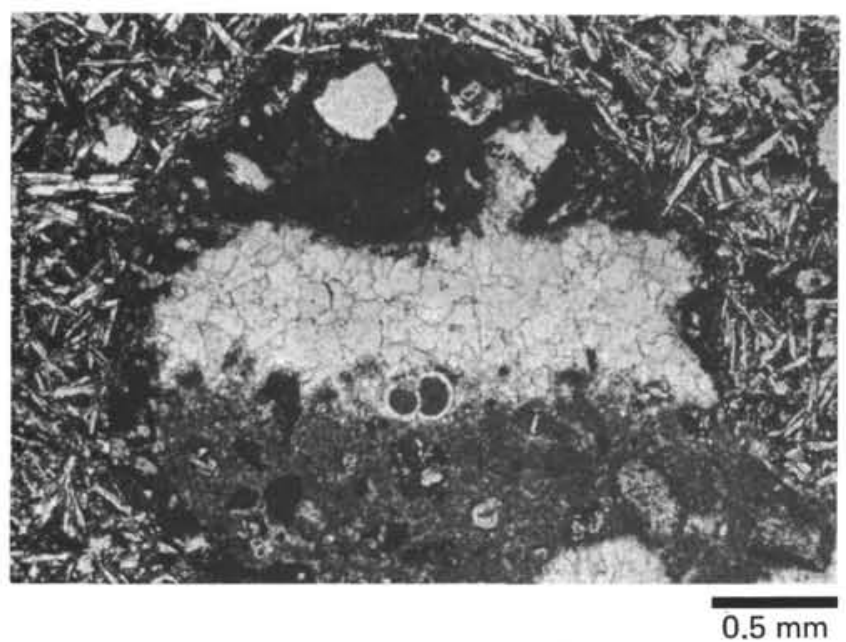

Figure 9. Photomicrograph of filled vesicle in basalt clast; geopetal floor of pelagic limestone with foraminiferal tests and basaltic clasts (dark) overlain by roof of voidfilling sparry calcite. Scale bar is $500 \mu \mathrm{m}$. Sample $373 \mathrm{~A}-3-3,32-40 \mathrm{~cm}$ (reversed image from lower-left part of Figure 5).
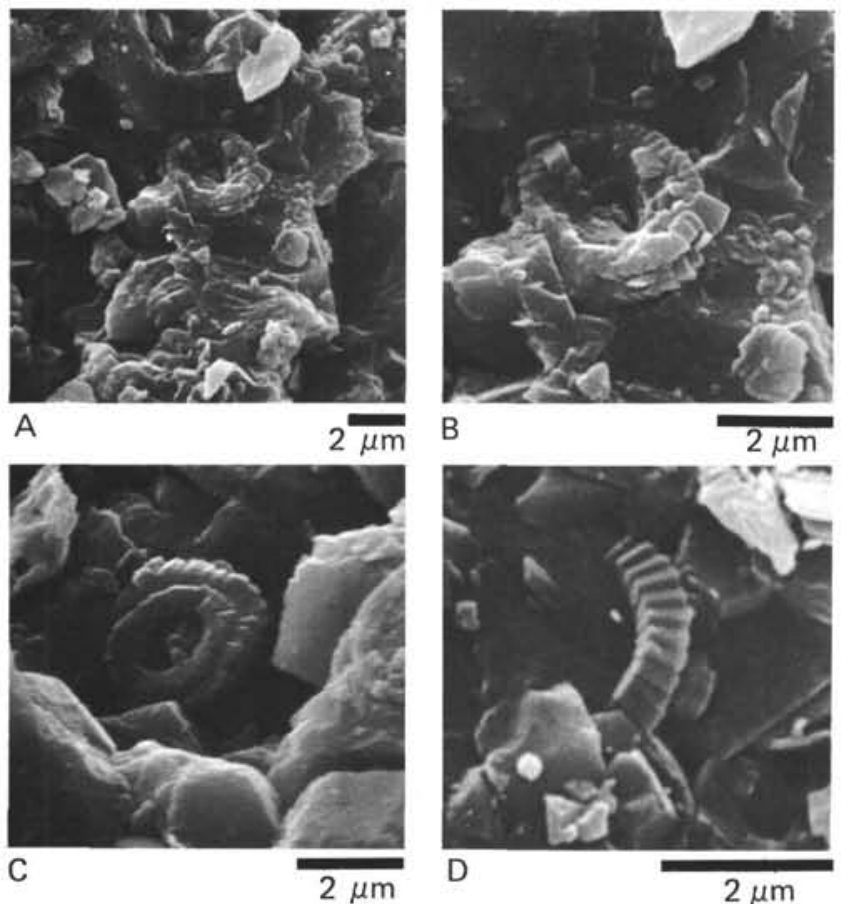

Figure 10. Scanning electron micrographs of the micritic matrix in P limestones. (A) Coccoliths in blocky matrix of cement, Sample 373A-5-2, $93 \mathrm{~cm}$. (B) Enlargement of $(A)$ showing secondary calcite overgrowths on a coccolith. (C) Coccolith surrounded by anhedral to subhedral secondary calcite crystals. Sample 373A-4-1, 134 $\mathrm{cm}$. (D) Coccolith enveloped and partly replaced by secondary calcite, Sample 373A-3-2, $127 \mathrm{~cm}$. Scale bars are $2 \mu \mathrm{m}$.

$\mathrm{Mg}, \mathrm{Al}, \mathrm{Si}$, and $\mathrm{S}$ are abundant. Where $\mathrm{S}$ is abundant there is little or no $\mathrm{Si}$, and vice versa. The absence of iron co-existing with the sulfur excludes pyrite as the source of the sulfur. We believe this material is a

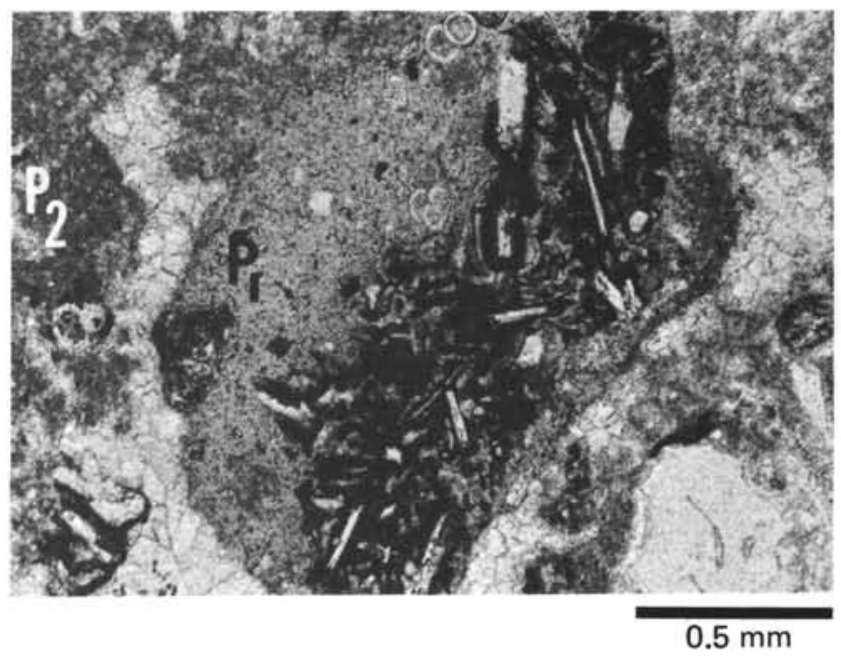

Figure 11. Basalt clast in center has a coating of forambearing $P_{1}$ limestone which is largely replaced by zeolites. The clast is cemented in foram-bearing $P_{2}$ limestone and $C_{1}$ sparry calcite cement. Scale bar is 500 $\mu \mathrm{m}$. Sample $373 \mathrm{~A}-3-3,76-78 \mathrm{~cm}$.

mixture of clay minerals with basal reflections at $11 \AA$ and at $7.5 \AA$; this mixture probably includes some of the following: nontronite, montmorillonite, sepiolite, and/or saponite. This material seems to be equivalent to the "mineral X" found by von Rad (1974) in basaltic rocks from Atlantic seamounts (and reported also to contain sulfur), and to the unidentified rim cement around basaltic clasts from Surtsey (Alexandersson, 1972).

\section{ISOTOPE GEOCHEMISTRY}

Table 1 presents, along with the dolomite analysis previously discussed, isotopic analyses of three P limestones, one D limestone, and one calcitic cement. All three kinds of calcitic carbonates have approximately the same values, and all are in equilibrium with each other and apparently also with the pore water with which they were in contact. From these data we may surmise that the lithification of the sediments and precipitation of the cements occurred in low temperature marine pore waters. Using the oxygen-18 content of modern Tyrrhenian seawaters (Cortecci et al., 1974), we calculate a value of $6^{\circ}$ to $8^{\circ} \mathrm{C}$ for the temperature of formation of both the cements and the lithified carbonates from the fractionation equation of O'Neil et al. (1969). This temperature range indicates that the calcitic cement was thus not a hydrothermal precipitate. The cement was probably precipitated directly from interstitial waters at deep-sea temperatures, and we may surmise that the diagenetic sediment formed similarly. The relatively high $\delta^{13}$ values indicate the absence of biologic influence in the cementation and lithification processes. The carbon-13 content appears to have been controlled primarily by a process of equilibrium exchange with atmospheric $\mathrm{CO}_{2}$ diagenesis.

Bonatti et al. (1974) found similar positive $\delta^{18}$ for calcitic cements in ultramafic breccias from the equato- 


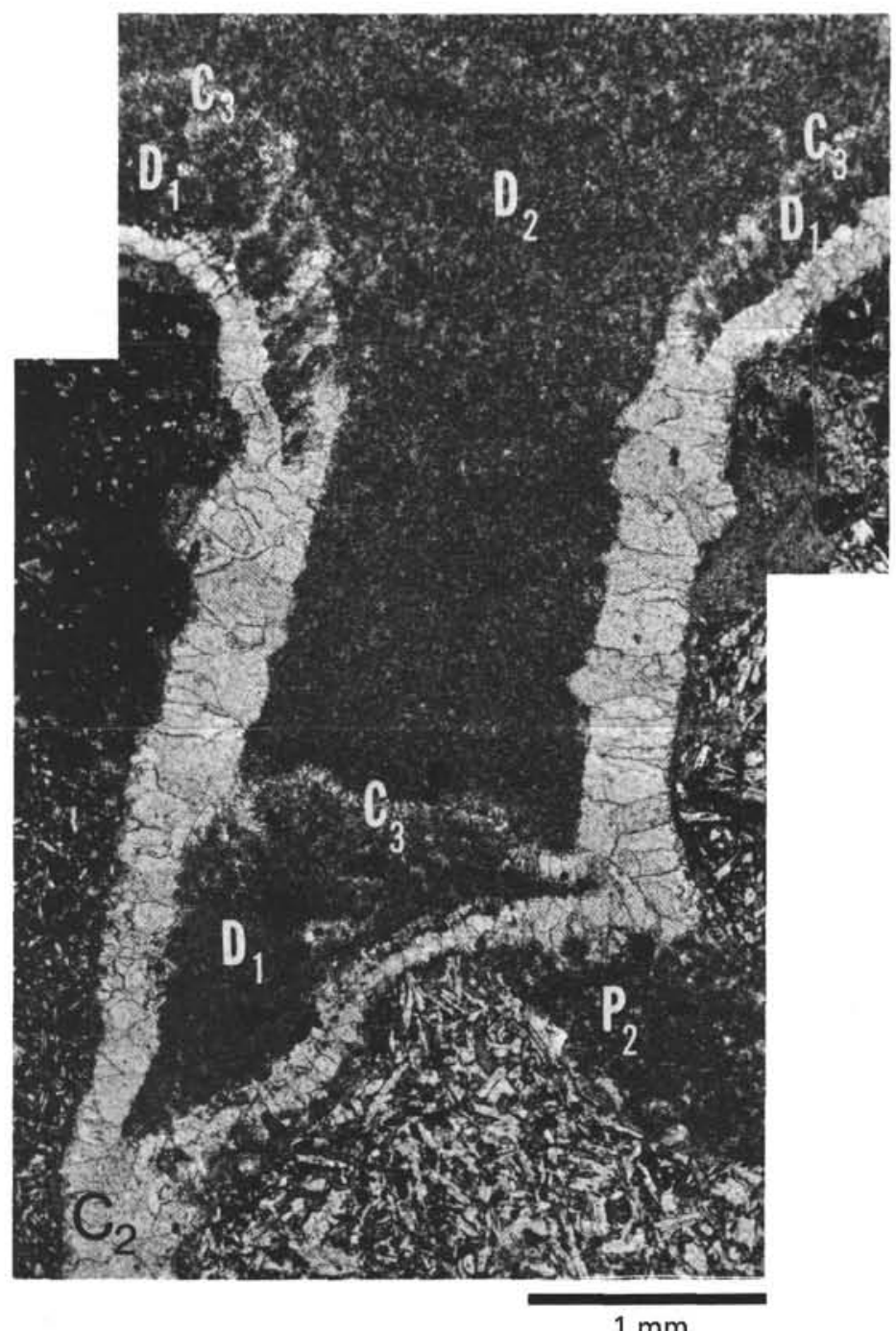

$1 \mathrm{~mm}$

Figure 12. Enlarged view of a portion of Figure 8 near the top, reversed image. Here the sequence of diagenetic sediment infills and cements is especially clear. Overlying basalt clasts and $P_{2}$ limestone is $C_{2}$ sparry calcite cement, locally containing a very thin lamina of sediment that apparently infiltrated during spar growth. $D_{1}$ sediment accumulated in the depression at center and on the tops of the protruding basalt clasts at left and right, but not on their steep sides. A very thin rim of $C_{3}$ cement formed above $D_{1}$ sediment, but it merges with $C_{2}$ and becomes indistinguishable where $D_{1}$ is lacking on the steep flanks of the basalt clasts. The final event is infiltration of $\mathrm{D}_{2}$ sediment. Scale bar is $1 \mathrm{~mm}$. Sample 373A-3-3, 76-78 $\mathrm{cm}$.

rial Mid-Atlantic Ridge. Lloyd and Hsü (1972) also derived very similar values from a "marble" at the contact with basalt at DSDP Site 14. Garrison et al. (1973) reported isotopic values from secondary calcites in basalt fractures from the Mid-Atlantic Ridge that likewise indicate precipitation at very low temperatures.

The fact that the $\mathrm{P}$ limestones, with their high content of calcareous plankton, do not show the warm temperatures of surface seawater suggests that isotopic re-equilibriation with pore waters occurred during diagenesis and cementation. Electron microscopic observations tend to support this, as they indicate considerable diagenesis in the micritic matrix of the limestones (Figure 10).

The difference between the $\delta^{18}$ ratio of the calciumrich dolomite of Core 2 and the calcites is $+2.4 \%$, which falls within the predicted range determined by Fritz and Smith (1970) for carbonates precipitating from the same solution at the same temperature. This 


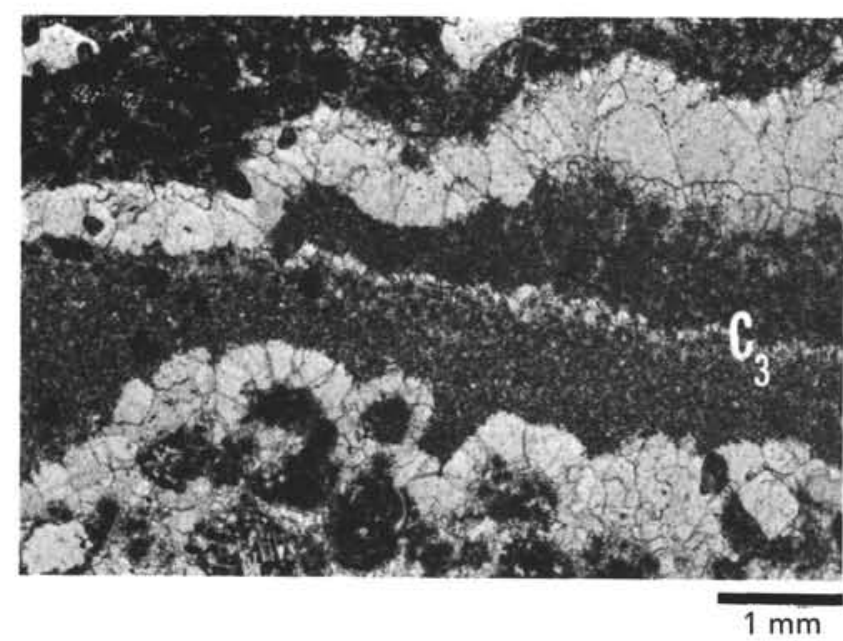

Figure 13. Photomicrograph of fracture filling in basaltic breccia. Sparry calcite cement rims the fracture at top and bottom. Diagenetic sediment $\left(D_{1}\right)$ fills in the floor and is overlain to the right by a very thin crust of $C_{3}$ sparry calcite. Note how competition between sediment infill and spar growth to the left has made the upper rim cement thinner on this side than on the right side. $D_{2}$ limestone lies above $C_{3}$ cement on the right. Scale bar is $1 \mathrm{~mm}$. Sample 373A-4-1, 134-137 cm.

differential value indicates further that both carbonates precipitated in isotopic equilibrium from a similar solution, a cold marine water.

\section{SUMMARY OF EVENTS}

On the basis of the observations given in previous sections of this report, we may list the following major events in the history of these breccias, from oldest to youngest:

1) Eruption of basaltic magma, and brecciation, the latter probably in several stages that included epiclastic as well as magmatic fragmentation.

2) Local brecciation and stripping of palagonitized rims of basalt clasts to form T sediments. Some transport (e.g., by slumping) may be involved leading to mixing of different types of basalts and the formation of polygenic breccias.

3) Infiltration of pelagic carbonate ooze $\left(P_{1}\right)$ into voids between and within fine-grained volcanic debris.

4) Lithification and some zeolitization of $P_{1}$ sediment.

5) Further brecciation to produce clasts of $P_{1}$ sediment.

6) Infiltration of $\mathrm{P}_{2}$ pelagic sediment.

7) Incipient lithification of $\mathrm{P}_{2}$ sediment to form a weakly lithified limestone.

8) Some fragmentation of $\mathrm{P}_{2}$ sediment to produce crumbly clasts.

9) Precipitation of $C_{1}$ sparry calcite cement.

10) Fracturing that produced open cracks up to several centimeters across.

11) Precipitation of $\mathrm{C}_{2}$ sparry calcite rim cement along with minor phillipsite.
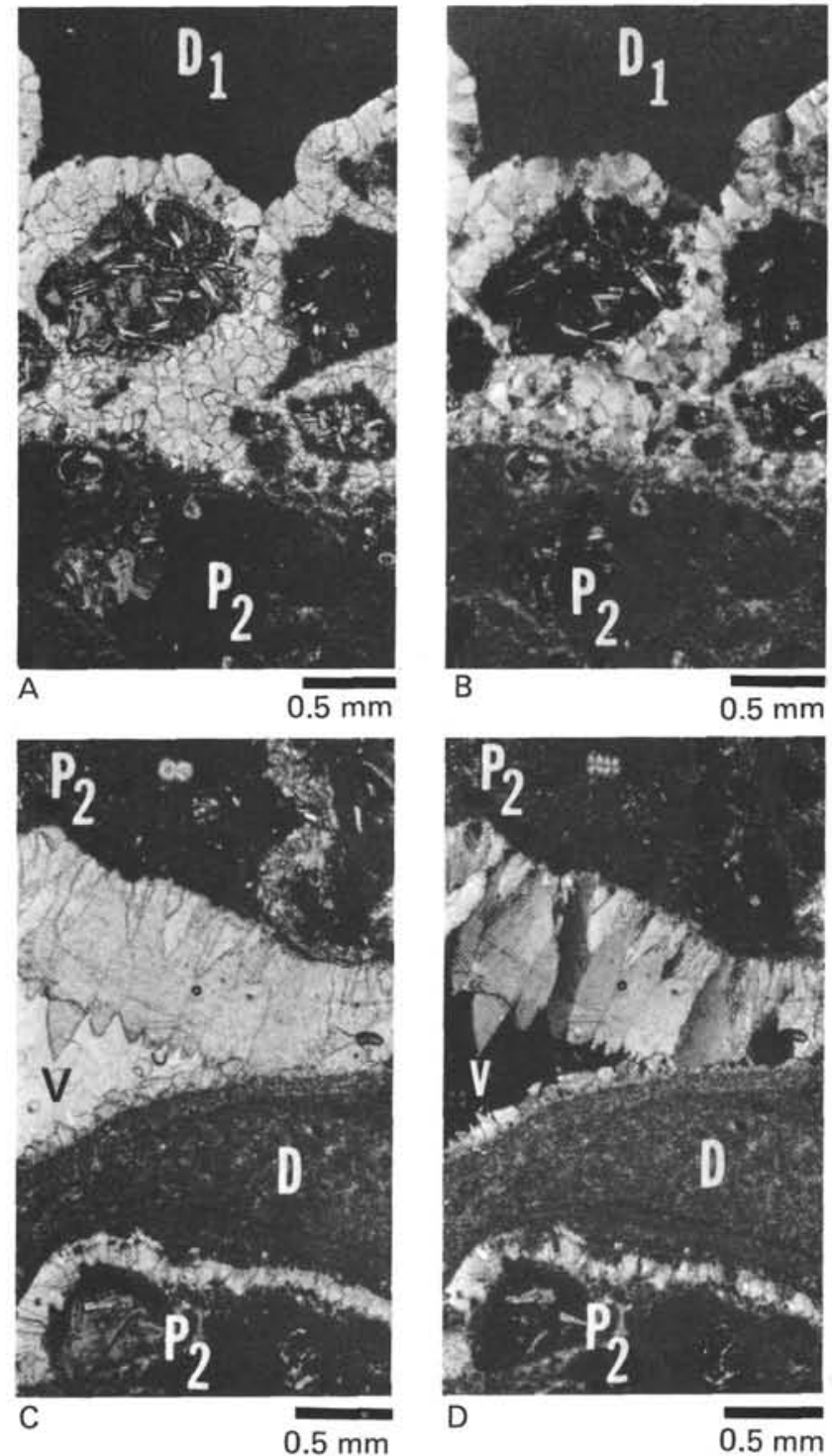

Figure 14. Photomicrographs of fracture fillings in $a b a$ saltic breccia. (A) $P_{2}$ limestone is below the fracture. $A$ number of angular pieces of basalt and $P_{2}$ limestone rest on the floor of the fracture; they may be caved pieces of the roof. Sparry calcite cement forms rims around them, and $D_{1}$ diagenetic sediment was deposited above. (B) Same view as (A), crossed nicols. (C) $P_{2}$ limestone borders a fracture that is rimmed by sparry calcite cement and partly infilled by diagenetic sediment (D). $V$ indicates an unfilled void. The bottom of the void has a rim cement of $C_{4}$ sparry calcite (not labelled). Note the much greater thickness of the rim cement at the top of the fracture compared to those on the bottom. (D) Same view as (C), crossed nicols. Scale bars are $500 \mu \mathrm{m}$. Sample 373A-3-3, 6-11 cm.

12) Deposition of $D_{1}$ diagenetic sediment.

13) Precipitation (locally) of $\mathrm{C}_{3}$ sparry calcite cement.

14) Deposition of $\mathrm{D}_{2}$ diagenetic sediment.

15) Precipitation of $\mathrm{C}_{4}$ sparry calcite cement. 


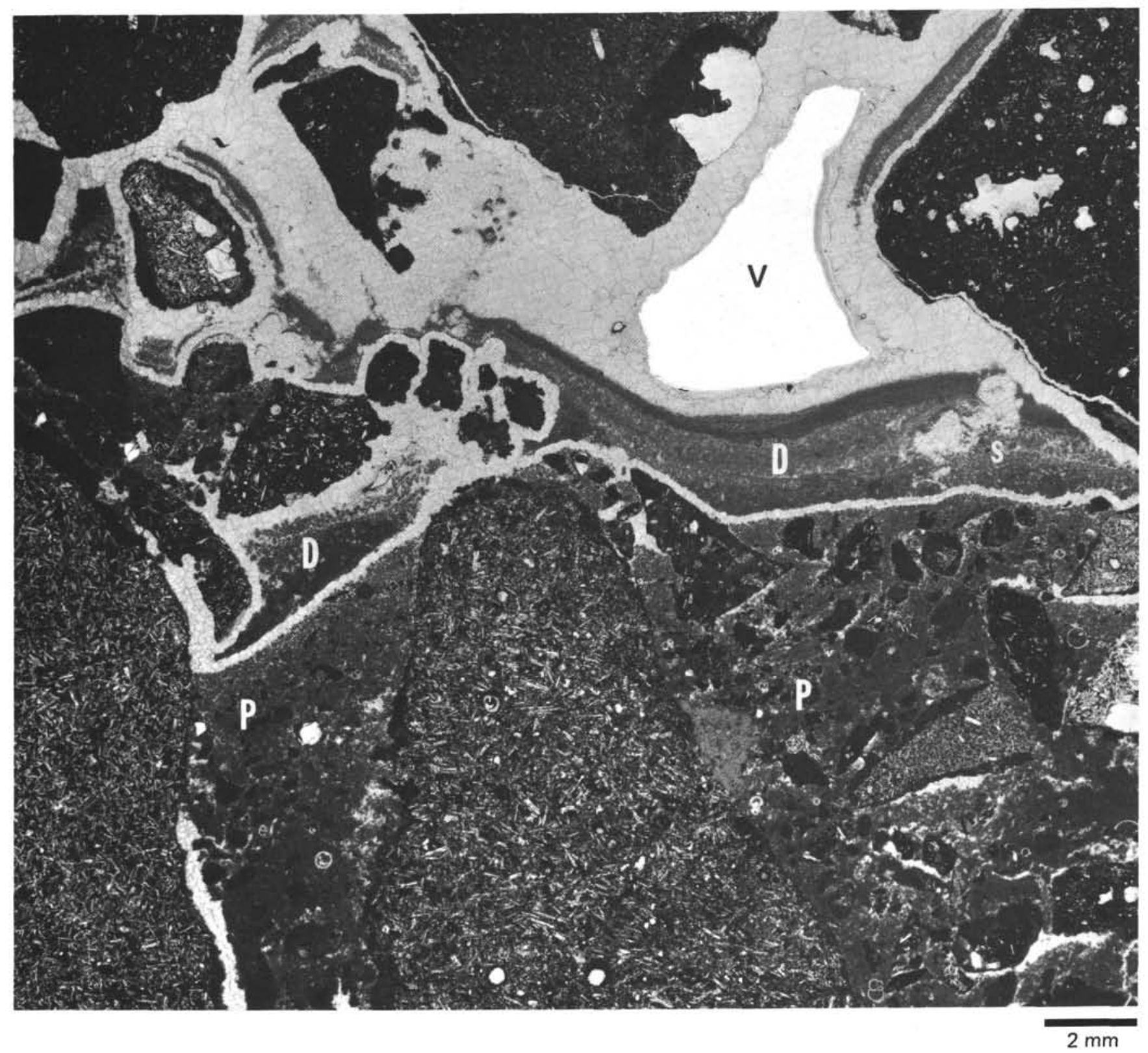

Figure 15. Thin-section photograph of breccia showing a variety of interclast sediment infillings and cements. Two areas of $P$ limestones, bottom right and left, include clasts of $P_{1}$ limestone and basalt cemented in $P_{2}$ limestone. Upper half is mainly sparry calcite cement (white) and diagenetic limestone (D), the latter forming geopetal floors. Calcite cement is of several generations, including weakly developed $C_{3}$ at the level on letter " $S$ " on the right. Note numerous shelters or "umbrellas" below dark volcanic clasts, now filled with spar (especially in lower right quadrant). Also note that ceiling sparry cement rims are much thicker than those on the floors. A large unfilled vug (V) is at upper right. Scale bar is 2 mm. Sample 373A-3-3, 85-89 cm.

\section{Vertical Distribution of Carbonates}

The complete sequence of interclast filling comprises the materials we have designated as $\mathrm{T}, \mathrm{P}_{1}, \mathrm{P}_{2}, \mathrm{C}_{1}, \mathrm{C}_{2}$, $\mathrm{D}_{1}, \mathrm{C}_{3}, \mathrm{D}_{2}$, and $\mathrm{C}_{4}$. This complete sequence, however, is well developed only in the upper part of the breccias, represented in our sampling from the base of Core 2 to about the middle of Core 4 . Below this point, $\mathrm{P}$ limestones become less abundant and the proportion of volcanic debris in them increases significantly (Figures 6 and 21). Diagenetic limestones appear to become proportionately more abundant (Figure 4), perhaps because considerable void space, unfilled by sediment, remained at the time of their deposition.

Both P and D limestones decrease markedly below the middle of Core 5 . The breccias in Cores 6, 7, and 8 appear to lack interclast limestone entirely; volcanic debris (T) and sparite fill most of the interstices (Figure 7), and much unfilled void space remains.

The data listed above suggest that pelagic sediment filtered in quantity into voids down to depths of about 40 meters below the sea floor, and in small amounts 

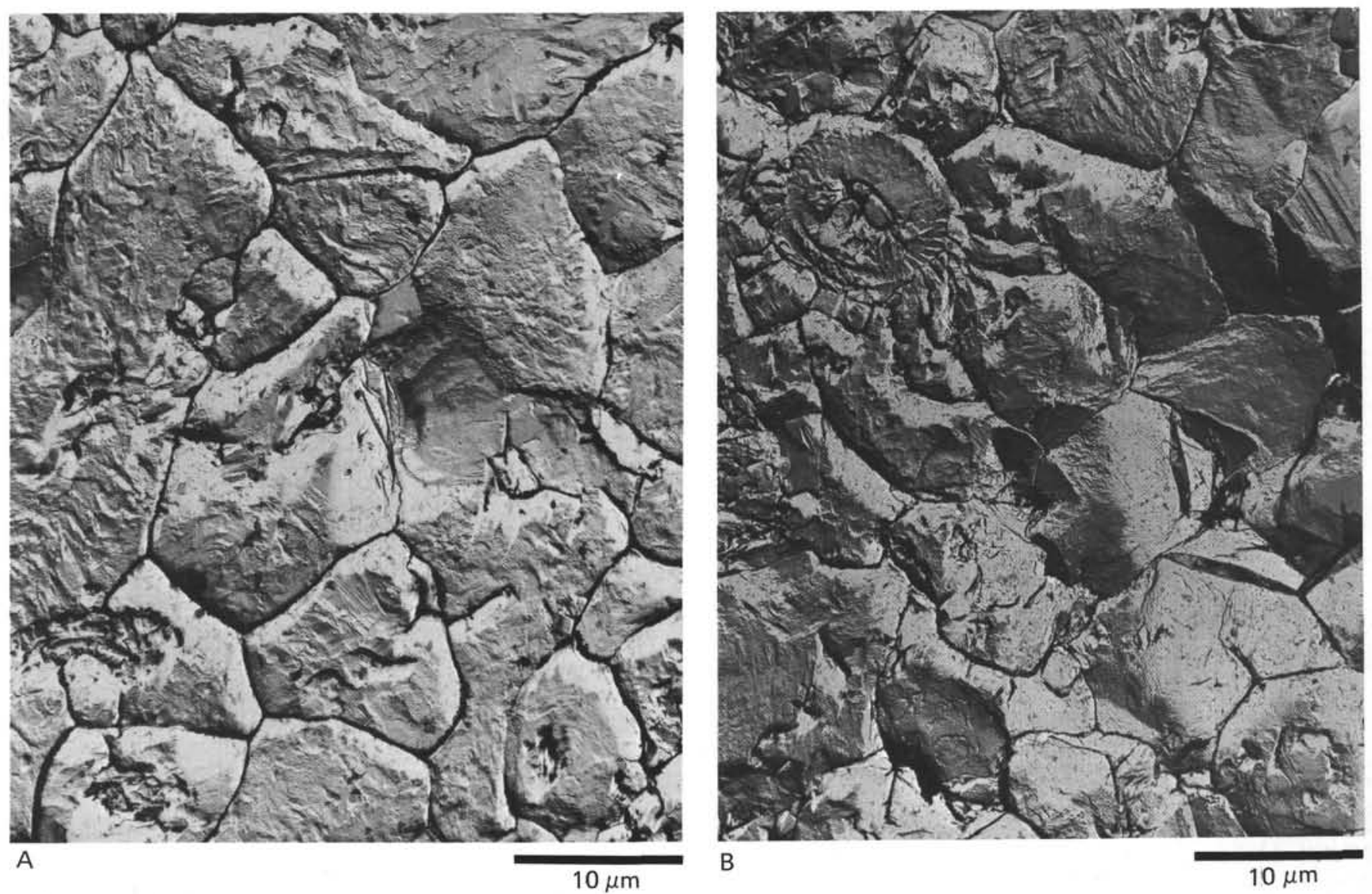

Figure 16. Transmission electron micrographs of D limestones. Sample $373 A-4-3,72-75 \mathrm{~cm}$. (A) Blocky mosaic of anhedral crystals. (B) Blocky mosaic of anhedral crystals with rare, partly recrystallized coccolith at upper left corner. Scale bars are $10 \mu \mathrm{m}$.

down to at least 70 meters. The fact that the D limestones persist in larger amounts to somewhat greater depths than the $\mathrm{P}$ limestones tends to support our contention that $\mathrm{D}$ sediment formed within the basaltic breccia during diagenesis.

The lack of interclast carbonate sediment below Core 5 doubtless results in part from the relatively large depth below a major source of sediment on the sea floor. But an even more important factor may have been the presence of basaltic flow rocks interstratified with the breccias. Such rocks occur in Cores 5 and 7 , and they are probably also present in the uncored intervals between Cores 5, 6, and 7. These comparatively dense flow rocks would serve to impede or block entirely the downward movement of pelagic sediment from the sea floor, as well as restrict the flow of interstitial water that could transport and deposit both $\mathrm{P}$ and $\mathrm{D}$ sediments.

\section{Geopetal Indicators}

These breccias contain a number of unequivocal geopetal or top-bottom indicators. Because these may prove useful to geologists attempting to unravel structure in basaltic rocks of complexly deformed eugeosynclinal regions, we summarize some of the more important ones below:
1) Former voids with flat-topped sediment floors and roofs of void-filling sparry calcite (Figures 7 and 9) or of spar and unfilled void space (Figures 14[C], 14[D], and 15).

2) Cavities sheltered beneath large clasts, now filled with sparry calcite (Figures 5, 8, and 15).

3 ) Sediment perched on top of steep-sided prominences (Figures 8, 12, and 15).

4) Sediment draped over protuberances on the floors of former voids (Figures 15 and 17).

5) Sediment filling in depressions and leveling out the relief of irregularities on the floor of former voids (Figures 4, 8, and 12).

6) Thick rim cements on the roofs of former voids, thinner ones on the floors (Figures 4, 8, 13, $14[\mathrm{C}], 14[\mathrm{D}]$, and 15).

7) Pieces of roof material accumulated on the floor of a former void (Figures 5, 13, and 17).

8) Competition between sediment infill and growth of rim cement in voids (Figures 13 and $14[\mathrm{C}]$ ).

\section{DISCUSSION}

Among the problems which emerge from the data presented in this paper are questions concerning the sources of the internally redeposited sediments and the manner in which they were transported and deposited 


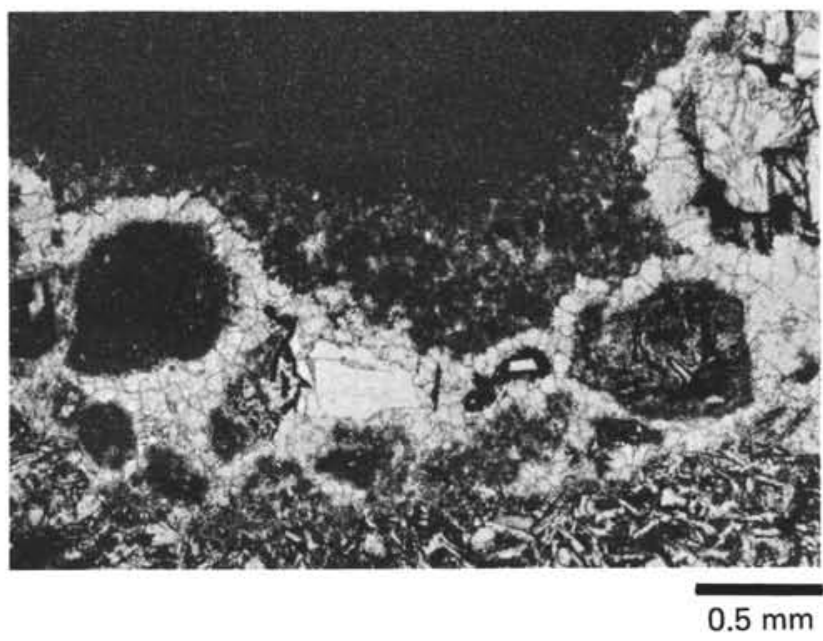

Figure 17. Enlargement of a part of Figure 5, reversed image. Clasts of basalt rest on the floor of a fracture and are rimmed by $C_{2}$ sparry calcite cement. The sediment above the clasts is $D_{1}$ diagenetic limestone of two kinds. Directly above the clasts is a mixture of pellet-like grains cemented in spar (structure grumeleuse); note how this drapes over irregularities to the right. This is overlain by homogeneous micrite. Scale bar is $500 \mu \mathrm{m}$. Sample 373A-3-3, 32-40 cm.

in breccia interstices. P limestones were clearly pelagic sediments redeposited downward from the sea floor under the influence of gravity. Their transport may have been aided also by water currents, but the sediments themselves contain no structures or textures indicating this.

The problem of the D limestones is just the opposite. We are not completely certain about their source, although we believe they are products of diagenetic precipitation. But, in contrast to the $\mathrm{P}$ limestones, they show several indications that currents transported and deposited them; these include lamination, particle size sorting, and erosional scour (cf. Figure 5).

Many unfilled interclast pores still remain in the breccias, and doubtless the original breccia contained numerous large, interconnecting voids through which both sediments and water could easily move. This system would of course tend to become plugged as the voids filled with sediment and cement. But the repetitive eposides of brecciation and fracturing acted to maintain an open system by creating new passageways.

Our observations strongly suggest that large volumes of water moved through the pore systems of this breccia. This seems required, not only to explain sediment transport; a continuous renewal of pore fluid appears necessary also to account for the relatively large volume of calcite cement in these rocks (cf. Dunham, 1969, p. 161). At first glance it is not easy to imagine what mechanism might cause such circulation. Hydrothermal convection is a possibility, yet the isotopic composition of the cements appear to argue against this. Water motion from deep bottom currents could probably be transmitted into the pore system of the breccia for some meters. Lowrie and Heezen
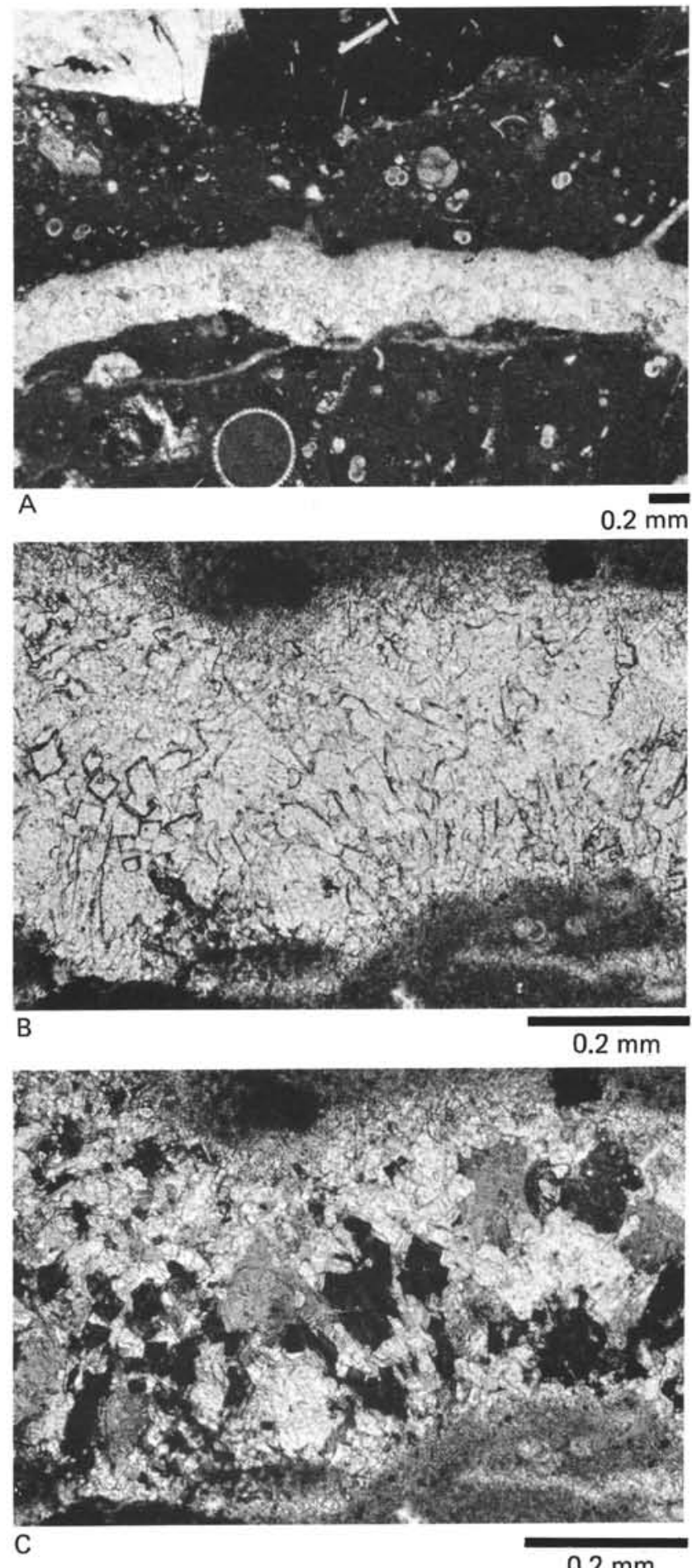

$0.2 \mathrm{~mm}$

Figure 18. Photomicrographs of small, calcite-filled vein cutting $P_{2}$ limestone. The vein also contains euhedral zeolite crystals, intergrown with the calcite, most visible in (C). Electron microprobe analysis indicates the vein calcite contains $4.2 \mathrm{Mol} \% \mathrm{Mg} \mathrm{Co}$. (A) General view. (B) Enlarged view, plain light. (C) Same as (B), crossed nichols. Scale bars are $200 \mu \mathrm{m}$. Sample 373A3-2, 48-52 cm.

(1967) have shown how sea-floor prominences like seamounts act to deflect bottom currents. A decelerated 

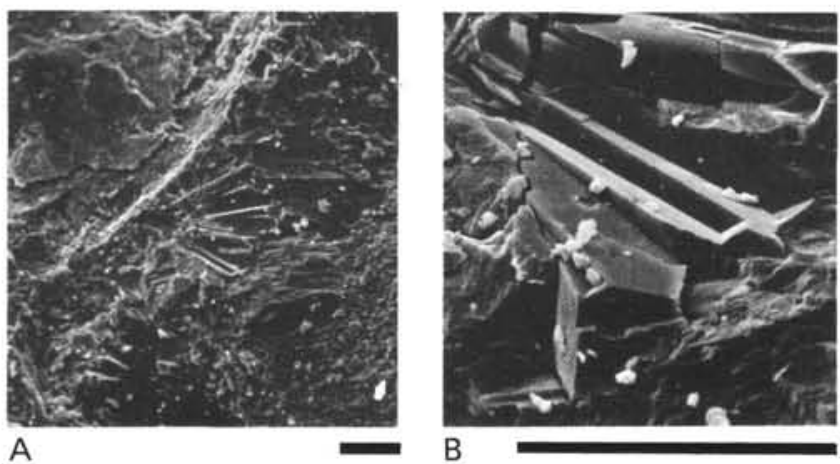

Figure 19. Scanning electron micrograph of calcite veinlet in basalt, with intergrown zeolite crystals. (A) General view of veinlet, which extends from lower left to upper right. Zeolites in center, basalt in upper left, diagenetic sediment at lower right. (B) Enlarged view of zeolites. Prismatic crystal terminations at lower right suggest this is phillipsite. Scale bars are $50 \mu \mathrm{m}$. Sample 373A-5-2, $93 \mathrm{~cm}$
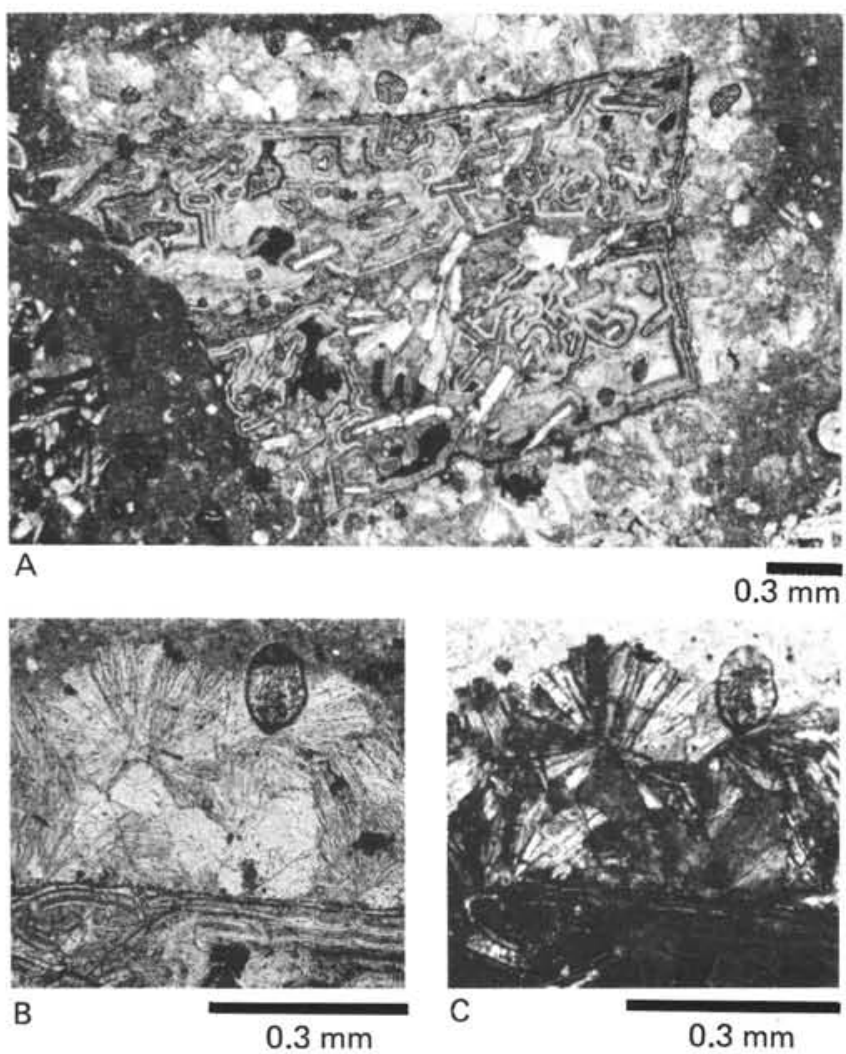

Figure 20. Photomicrographs of basaltic alteration products. (A) Palagonite clast surrounded by rosettes of unidentified platy or fibrous mineral that grew from the clast wall and replaced the surrounding $P_{2}$ limestone. (B) Detail of contact between palagonite clast and rosettes, plain light. (C) Same as (B), crossed nichols. Scale bars are $300 \mu \mathrm{m}$. Sample $373 A-3-2,142 \mathrm{~cm}$.

region on the lee side of the seamount allows accumulation of a thick sediment wedge there. Current velocities around the sides of the seamount parallel to the

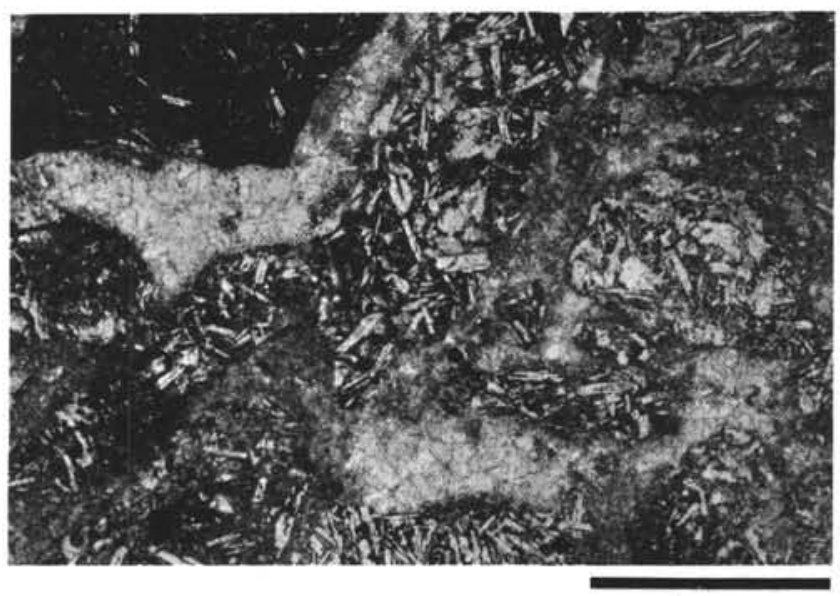

$1 \mathrm{~mm}$

Figure 21. Photomicrograph of sediment-poor part of the breccia in the bottom part of Core 5. Basalt fragments are cemented mainly in sparry calcite and a small amount of microspar. Scale bar is $1 \mathrm{~mm}$. Sample $373 A-5-3,70-73 \mathrm{~cm}$.

flow become, on the other hand, increased. Thus, those flanks of the seamount which lie parallel to strong bottom currents would seem the most likely sites for transmission of large quantities of water through surficial volcanic breccias and perhaps also for extensive calcitic cementation.

Downward flow of both sediment and water into breccia interstices might also result from vertical density currents. Bradley (1965) has demonstrated experimentally the effectiveness of this mechanism in transporting and depositing fine-grained sediment at relatively rapid rates. Vertical density currents originate in small areas when a critical mass of sediment particles accumulate; the areas of densely concentrated particles are heavier per unit volume than surrounding water with less sediment, thus these areas sink vertically as density currents. In Hole $373 \mathrm{~A}$, both $\mathrm{P}$ and $\mathrm{D}$ sediments may have been transported downward in this manner.

One might expect deep-water calcitic cementation of mafic igneous breccias to be rare since normal seawater at bathyal to abyssal depths should be highly undersaturated with respect to all forms of calcium carbonate. Yet breccias of these kinds that are cemented by low temperature calcite are apparently rather common in the present ocean basins (Nayudu, 1964; Milliman, 1971; Thompson, 1972; Garrison et al., 1973; Bonatti et al., 1974). The explanation may lie in the submarine diagenetic alteration of basalts and other mafic rocks. Among the postulated effects of palagonitization and other low-temperature alteration effects are pronounced increases in the $\mathrm{pH}$ and calcium concentration of pore waters. Both would tend to promote precipitation of $\mathrm{CaCO}_{3}$, especially in the presence of preexisting carbonate sediments (Thompson, 1972; Garrison et al., 1973; see also Hay and Ijima, 1968, and Bonatti et al., 1974). Accompanying chemical alteration might also be expected to form phillipsite, montmorillonite and other silicates (Keene et al., 1976). 
Folk and McBride (1976) have employed several kinds of textures and structures present in these breccias, especially mud-textured internal sediment and geopetal structures, to suggest that Jurassic ophicalcite breccias in the northern Apennines formed during subaerial exposure. Clearly, however, these kinds of textures can form also in the deep marine environments, as in Hole 373A.

\section{ACKNOWLEDGMENTS}

We are grateful to the staffs of the Geologisch-paläontologisches Institut in Basel and the Earth Sciences Board in Santa Cruz for help in preparation of the specimens and manuscript. A grant from the Faculty Research Committee of the University of California, Santa Cruz, helped to defray some expenses of the research. We express appreciation to Aaron C. Waters for review of the manuscript and for many helpful suggestions.

D. Bernoulli thanks the Swiss National Science Foundation for support during this project (Grant 2.125-0.74). R. Guggenheim provided facilities at the SEM-Laboratory at the Geological Institute of Basel University; Mrs. L. Luginbühl operated the microscope and prepared the photomicrographs. The help of S. Graeser and H. Schwander (Basel) in mineralogical and geochemical questions and E. Gonzales and L. Mack (Santa Cruz) in sample preparation is gratefully acknowledged.

The stable isotope analyses were carried out at the Laboratorio di Geologia Nucleare, Pisa, Italy.

\section{REFERENCES}

Alexandersson, T., 1972. The sedimentary xenoliths from Surtsey: turbidites indicating shelf growth: Surtsey Prog. Rept., v. 6, p. 1-16.

Bathurst, R. G. C., 1958. Diagenetic fabrics in some British Dinantian limestones: Liverpool Manchester Geol. J., v. 2, p. 11-26.

Bathurst, R. G. C., 1975. Carbonate sediments and their diagenesis (2nd ed.): Amsterdam (Elsevier Scientific Publish. Co.).

Beales, F. W., 1965. Diagenesis in pelleted limestones. In Pray, L. C. and Murray, R. C. (Eds.), Dolomitization and limestone diagenesis: Soc. Econ. Paleontol. Mineral., Spec. Publ. 13, p. 49-70.

Bonatti, E., Emiliani, C., Ferrara, G., Honnorez, J., and Rydell, H., 1974. Ultramafic carbonate breccias from the equatorial Mid Atlantic Ridge: Mar. Geol. , v. 16, p. 83102.

Bradley, W. H., 1965, Vertical density currents: Science, v 150 , p. $1423-1428$

Carlisle, D., 1963. Pillow breccias and their aquagene tuffs, Quadra Island, British Columbia: J. Geol., v. 71, p. 48-71.

Cayeux, L., 1935. Les Roches Sédimentaires de France: Roches Carbonatées: Paris (Masson).

Cortecci, G., Noto, P., and Molcard, R., 1974. Tritium and sulfate-oxygen isotopes in the Mediterranean Sea: Some profiles in the low Tyrrhenian Basin: Boll. Geofisica Teorica Applicata, v. 16, p. 292-298.

Degens, E. T. and Epstein, S., 1964. Oxygen and carbon isotope ratios in coexisting calcites and dolomites from recent and ancient sediments: Geochim. Cosmochim. Acta, v. 28, p. 23-44.

Dunham, R. J., 1969. Early vadose silt in Townsend Mound (reef), New Mexico. In Friedman, G. M. (Ed.), Deposi- tional environments in carbonate rocks: Soc. Econ. Paleontol. Mineral. Spec. Publ. 14, p. 139-181.

Folk, R. L. and McBride, E. F., 1976. Possible pedogenic origin of Ligurian ophicalcite: a Mesozoic calichified serpentinite: Geology, v. 4, p. 327-332.

Fontes, J. C. and Desforges, G., 1975. Oxygen 18, carbon 13 and radiocarbon as indicators of a Würmian cold and deep diagenesis in western Mediterranean carbonate sediments: Ninth Congr. Internat. Sedimentol., Nice, v. 8, p. 29-38.

Fritz, P. and Smith, D. G. W., 1970. The isotopic composition of secondary dolomites: Geochim. Cosmochim. Acta, v. 34 , p. $1161-1173$.

Garrison, R. E., 1974. Radiolarian cherts, pelagic limestones, and igneous rocks in eugeosynclinal assemblages. In Hsü, K. J. and Jenkyns, H. C. (Eds.), Pelagic sediments: on land and under the sea: Internat. Assoc. Sedimentol., Spec. Publ. 1, p. 367-399.

Garrison, R. E., Hein, J. R. and Anderson, T. F., 1973, Lithified carbonate sediment and zeolitic tuff in basalts, Mid-Atlantic Ridge: Sedimentology, v. 20, p. 399-410.

Goldsmith, J. R. and Graf, D. L., 1958. Relation between lattice constants and composition of the $\mathrm{Ca}-\mathrm{Mg}$ carbonates: Am. Mineralogist, v. 43, p. 84-101.

Hay, R. L. and Iijima, A., 1968. Nature and origin of palagonite tuffs of the Honolulu Group on Oahu, Hawaii. In Coats, R. R., Hay, R. L., and Anderson, C. A. (Eds.), Geol. Soc. Am. Mem. 116, p. 331-376.

Keene, J. B., Clague, D. A., and Nishimori, R. K., 1976. Experimental hydrothermal alteration of tholeiitic basalt in seawater: resultant mineralogy and textures: J. Sediment. Petrol., v. 46, p. 647-653.

Lloyd, R. M. and Hsü, K. J., 1972. Stable-isotope investigations of sediments from DSDP III cruise to South Atlantic: Sedimentology, v. 19, p. 45-58.

Lowrie, A., Jr., and Heezen, B. C., 1967. Knoll and sediment drift near Hudson Canyon: Science, v. 157, p. 1552-1553.

Milliman, J., 1971. Carbonate lithification in the deep sea. In Bricker, O. P. (Ed.), Carbonate sediments: Baltimore (John Hopkins University Press), p. 95-101.

Murata, K. J. and Erd, R. C., 1964. Composition of sediments from the experimental Mohole Project (Guadalupe Site): J. Sediment. Petrol., v. 34, p. 633-655.

Nayudu, Y. R., 1964. Palagonite tuffs (hyaloclastites) and the products of post-eruptive processes: Volcanol. Bull., v. 27, p. 1-20.

O'Neil, J. R., Clayton, R. N., and Mayeda, T. K., 1969. Oxygen isotope fractionation in divalent metal carbonates: J. Chem. Phys., v. 51, p. 5547-5558.

Riedel, W. R., Ladd, A. S., Tracey, J. I., Jr., and Bramlette, M. N., 1961. Preliminary drilling phase of the Mohole Project. II. Summary of coring operations: Am. Assoc. Petrol. Geol. Bull., v. 45, p. 1793-1798.

Sander, B., 1936. Beiträge zur Kenntnis der Anlagerungsgefüge (rhythmische Kalke und Dolomite aus der Trias: Mineral. Petrog. Mitt., v. 48, p. 27-209.

Sharma, T. and Clayton, R. N., 1965. Measurement of $\mathrm{O}^{18 /}$ $\mathrm{O}^{16}$ ratios of total oxygen of carbonates: Geochim. Cosmochim. Acta, v. 29, p. 1347-1353.

Thompson, G., 1972. A geochemical study of some lithified carbonate sediments from the deep-sea: Geochim. Cosmochim. Acta, v. 36, p. 1237-1253.

von Rad, U., 1974. Great Meteor and Josephine Seamounts (eastern North Atlantic): Composition and origin of bioclastic sands, carbonate and pyroclastic rocks: "Meteor"'Forsch.-Ergebnisse, Reihe C, p. 1-61. 